This is the peer reviewed version of the following article: Evans, L., Baskerville, R. and Nara, K. (2015), Colliding Worlds: Issues Relating to Language Translation in Accounting and Some Lessons from Other Disciplines. Abacus, 51:1-36.

doi:10.1111/abac.12040, which has been published in final form at

http://onlinelibrary.wiley.com/doi/10.1111/abac.12040/full 


\title{
Colliding Worlds: Issues Relating to Language Translation in Accounting and Some Lessons from Other Disciplines
}

\begin{abstract}
This paper explores implications of language translation in accounting. It draws on research on translation in other disciplines, and on insights from applied linguistics. It examines practical problems and solutions explored in other disciplines that we deem relevant to accounting. The paper also examines ideological, cultural, legal and political consequences of translation. We find that the ambiguity inherent in translation is, on the one hand, relevant for the translation of accounting principles and can contribute to accounting convergence. We show, on the other hand, that it has the potential to be exploited in ideologically or pragmatically motivated distortions in the implementation of accounting regulation. We further argue that the importance of translation in accounting is underestimated or disregarded, inter alia because it has limited effect on the culturally and economically most dominant stakeholders. We finally examine implications of translation problems for less powerful stakeholders and smaller language communities.
\end{abstract}

Key Words: language, translation, accounting regulation, other disciplines 


\section{INTRODUCTION}

Accounting, like other professions, is dependent on specialized terminology and concepts to communicate and conduct its business efficiently (Mills, 1989). Accounting has also become increasingly international, and accounting harmonization and convergence, and the efficient functioning of international capital markets, require translation of accounting terminology.

However, translation has been identified as one of the obstacles to equivalent implementation of International Financial Reporting Standards (IFRS) (Nobes, 2006; Zeff, 2007). Not only is translation itself problematic, but so is the understanding of certain concepts in cultures to which they are alien (Zeff, 2007). While translation is crucial to a process of globalization, its inherent difficulties mean that 'the equivalent interpretation and application of (foreign) concepts will always remain problematic' (Ho, 2004, p. 223). This also applies to accounting: while prior literature is limited, evidence suggests that translation is challenging and that equivalence is elusive. This is because language itself is inherently indeterminate and ambiguous, and because the conceptual underpinning of accounting is contingent on the knowledge bases of other traditions and disciplines (Zambon and Zan, 2000). However, there is, to date, little examination and exploration of translation problems in accounting research. In other disciplines, on the other hand, the implications of translation problems are more explicitly acknowledged, and a considerable body of research literature exists, for example, in medicine and law. Translation practices are not uniform across disciplines, and each discipline has its own individual, if not unique, concerns relating to translation and translatability. However, there are also many shared problems, and there is considerable overlap in approaches and solutions, as well as underlying cultural and political concerns.

This paper aims, therefore, to contribute to accounting research in the following ways. First, we provide a review of issues arising in translation in other disciplines which we deem relevant to accounting. ${ }^{1}$ We focus on research in law, advertising, medicine (and related disciplines), and natural sciences, technology and engineering. Second, we explore the implications of insights from this research for translation in accounting, in terms of practical as well as more fundamental ideological, cultural, legal and political concerns. We support our explications by drawing, additionally, on observations from applied linguistics, EU and IASB documents and correspondence with key informants, including IFRS translation experts. Finally, we aim to show that the importance of translation in accounting is underestimated or disregarded, and explore explanations for this disregard.

We find that much can be learned, in terms of practical problems and solutions, from research on translation in other disciplines that is of relevance to accounting. We also suggest that translation is not only a practical problem: accounting is not merely a neutral technical practice, but often serves more to legitimate the behaviour of individuals or organizations than to aid decision making (Power, 2003). We show that, on the one hand, the ambiguity inherent in accounting and legal language, and the need to retain this ambiguity to permit room for interpretation especially in principle-based law and principle-based standards, may facilitate accounting convergence (rather than standardization). On the other hand, its inherent flexibility permits its discursive and vested use in negotiations to facilitate compromise based on accidental or deliberate misunderstanding. We provide examples to show that indeterminacy in accounting terminology may be exploited in ideologically or pragmatically motivated distortions in translation and implementation. 
We finally argue and provide examples to show that the importance of translation in accounting is underestimated or disregarded, inter alia because translation does not explicitly affect the culturally and economically most influential players. Instead, translation-related problems disadvantage and disenfranchise less powerful stakeholders, especially smaller language communities or groups with lesser English language competencies. The lack of high quality, timely translations can delay IFRS implementation, exclude stakeholders from the consultation and implementation discourse, place undue and disproportionate costs on smaller jurisdictions and allow the most powerful players to control the dissemination of accounting thought.

Below we introduce translation work in the EU and by the IASB, provide a brief overview of prior research on language and translation in accounting, and present theoretical frameworks based on translation theories and 'languages for specific purposes' to inform our discussions in the latter parts of this paper. We then provide a review of research on translation in law, advertising, medicine and related disciplines, and technology and engineering. Based on the insights gained from this review, we explore their relevance to accounting. We focus initially on practical problems and solutions, before exploring in greater depth cultural, legal, political and ideological concerns and implications.

\section{TRANSLATION IN THE EU AND BY THE IASB}

The EU currently has 27 member states and 23 official languages. Its multilingual policy requires all citizens to have equal access to its laws and policies (European Commission, 2008). All official languages have equal legal standing. This is significant 'as a guarantee of legal certainty and as a democratic accountability tool' (Athanassiou, 2006, p. 6). As a result, translation work is required on an enormous scale (Athanassiou, 2006).

All EU institutions have their own translation services. The DirectorateGeneral for Translation of the Commission is, with 2,300 translators, by far the largest (Yankova, 2008, p. 135). Translation is aided by computer-assisted translation (CAT) tools and machine translation, which, however, require human editing (Cao, 2007, pp. 158-62). In an accounting context, translation affects the implementation of the EU's company law directives and regulations, including Regulation (EC) No $1606 / 2002$ on the application of international accounting standards. IAS/IFRS (as endorsed by the EU) now constitute EU law which is directly binding on the member states.

The working language of the IFRS Foundation is English, but according to its website, '[t]ranslation is a necessary and vital part of achieving the ... mission to develop a single set of high quality global accounting standards for use around the world'. ${ }^{2}$ The Foundation's translation process involves managing, overseeing and reviewing translations prepared by external experts (IASB Insight, 2008; see also Note 2). It supports only one translation for each language because multiple translations 'would endanger comparability, transparency, and the long-term sustainability of high-quality IFRS translations' (as Note 2). They would also potentially lead to 'the proliferation of legal arguments over the resulting arguable differences in financial reporting' (IASB Insight, 2008, p. 9). The Foundation is also creating a multilingual glossary, which currently contains approximately 1,500 IFRS key terms, used in its official translations. ${ }^{3}$

When IFRS were implemented in the EU, translation of the extant standards into the member states' languages was required. These translations were created 
partly by the Commission's Directorate-General for Translation and partly by the (then) IASC Foundation on behalf of the EU, with input from national governments and the Directorate-General for Translation. The latter has been preparing all translations of endorsed IFRS since June 2009, without input from the IFRS Foundation. However, the IFRS Foundation's translation team also continues to manage translations into European languages, in particular where they are also widely spoken outside Europe. As a result, and in spite of the Foundation's policy, different translations of IFRS continue to exist: while, for example, its own translations into Spanish and French attempt to find terminology acceptable also, respectively, to Latin-American and Canadian speakers of these languages, the EU's translations are based on the European language versions only. ${ }^{4}$

\section{PRIOR RESEARCH}

Early research on language in accounting investigated differences in the perception of accounting concepts. It applied techniques developed in psychology (e.g. Osgood et al., 1957) and was restricted to subjects whose first language was English. For example, Haried (1972, 1973), Oliver (1974), Adelberg (1979), Adelberg and Farrelly (1989) and Houghton and Hronsky (1993) provided evidence that the interpretation of many accounting concepts differs between different groups of subjects, such as preparers and users of accounting information, academics, students and members of different professional groups. According to Chesley (1986, p. 197), even within the same group (mature students), "[c]ommon words such as "probable" or "likely" will cause wide variations in interpretation and should not be used for specific communication of uncertainty in general situations sensitive to inaccurate interpretations'.

Early cross-cultural studies (Riahi-Belkaoui and Picur, 1991; Bagranoff, et al., 1994) explored the impact of national culture on the perception of accounting terminology by speakers of the same language and concluded that 'cross-cultural differences may affect the meaning of, and hence the application of, accounting principles' (Bagranoff et al., 1994, p. 35). The above examples suggest that perception and interpretation differ within and in particular between different groups of subjects speaking the same language. Such differences increase when translation into a different language is involved.

Early papers exploring translation examined selected accounting terms in EU accounting directives and their national implementations, but did not measure differences in perception (e.g. Rutherford, 1983; Parker, 1989; Zeff, 1990; Alexander, 1993; Nobes, 1993; Evans and Nobes, 1996; Aisbitt and Nobes, 2001; Nobes, 2009 (also with reference to IFRS)). This research found, inter alia, that concepts originating within a specific accounting culture, such as the 'true and fair view' (TFV) were not, as a rule, translated literally from the English original (Rutherford, 1983; Alexander, 1993; Nobes, 1993; Aisbitt and Nobes, 2001; Nobes, 2009), nor applied equivalently (e.g. Nobes, 1993; Aisbitt and Nobes, 2001; Kosmala MacLullich, 2003; Albu et al., 2013; see also Dahlgren and Nilsson, 2012).

Archer and McLeay (1991) explored translation of audit reporting and found that there appears to be no translinguistic register of accounting. This was attributed to a lack of semantic equivalence of accounting concepts in different cultures, as well as to pragmatic idiosyncrasies in language use. Evans (2004) explored the relevance of the Sapir-Whorf hypothesis for accounting (cf. Sapir, 1929/49; see below). This hypothesis suggests that linguistic categories affect thought and perception. This, in turn, has implications for translation, also in accounting. 
Differences in perception between speakers of different languages also affect the interpretation of probability/uncertainty expressions (such as 'probably', 'likely', 'remote'). For example, Davidson and Chrisman (1993, 1994) found that English probability expressions permit more precise interpretation than their French translations. Doupnik and Richter (2003, 2004) and Doupnik and Riccio (2006) provided further evidence of differences in interpretation of uncertainty expression in translation. This is important because different interpretations of probability expression may lead to differences in the use of International Accounting Standards (Doupnik and Richter, 2004). Finally, Huerta et al. (2013) found that there were more frequent differences, in translation by Mexican professional accountants, of generic words and phrases (such as 'renewable', 'timing', 'development') as compared to accounting-specific phrases (such as 'lease', 'asset', 'provision'). This has implications for the translation of principle-based standards, which contain higher proportions of generic phrases (ibid.).

The key issues arising from prior accounting literature on translation and language are as follows: (i) Perception and interpretation differ even between subjects speaking the same language; such differences are exacerbated by translation. (ii) There is no transnational register of accounting; in other words, accounting terminology and the underlying concepts differ internationally. (iii) Translation is especially problematic when it concerns culture-dependent concepts, such as TFV. Translation of such 'alien' concepts usually leads to a shift in meaning. (iv) Even near-equivalent translations (as, for example, those of probability expressions) are often interpreted differently.

These issues are important in the context of the internationalization of accounting, with the increasing implementation of international standards. However, prior research remains limited, in particular where the translation of IFRS is concerned. Prior accounting research also makes insufficient use of insights gained in other disciplines or in applied linguistics. We aim to address this gap. Below we introduce the theoretical frameworks informing this paper.

\section{LANGUAGES FOR SPECIFIC PURPOSES}

Where communication serves specific purposes, for example in the context of politics, sports or professions, highly specialized 'dialects' or varieties of language exist, referred to as 'registers' (Salmond, 1998), 'languages for specific purposes' (LSP) (e.g. Engberg, 2006) or 'jargon' (Crystal, 2003, p. 174; Allan, 2006; see also Evans, 2010). They draw on specialized terminology and may also have distinctive stylistic features. Legal English, for example, is characterized by terminology of Latin and French origin, archaic diction, redundancy, long sentences, and frequent use of the passive voice (Alcaraz Varó and Hughes, 2002, Chapter 1). Specialized terms such as 'barrister', 'solicitor', etc. derive their meaning from a legal context (Alcaraz Varó and Hughes, 2002, pp. 16-17), but legal English also contains words borrowed from everyday language, which however have a different meaning in the legal register (for example 'offer', 'consideration', 'assignment', 'performance' and 'remedy'; see Cao, 2007, p. 67). Such borrowing occurs in other languages as well as in English (Cao, 2007, p. 67).

The accounting LSP also contains many terms borrowed from everyday language which have a different meaning in accounting (such as 'share', 'material', 'reserve' or 'conservatism'). It also contains words borrowed from other disciplines, for example from economics or law. 
LSPs are part of a specific discipline or domain. They permit efficient communication by standardizing the use of terminology and interpretation of concepts (Engberg, 2006), and allowing speakers to capture finer distinctions than everyday language (Allan, 2006). The use of LSPs can also express occupational identity (Crystal, 2003, p. 370) and signal membership of a group, such as 'an intellectual or technical elite' (ibid., p. 174). Thus LSPs can enhance a speaker's image and the apparent significance of what is being said, while at the same time intimidating and excluding non-members (Allan, 2006). This is especially the case where speakers draw on Graeco-Latinate terminology (Engberg, 2006).

The translation of LSP terminology can be particularly problematic, partly because the translator needs to distinguish the LSP meaning of a term from its everyday meaning. In addition, definitions and usages change. In law, for example, terminology is constantly redefined because legislation changes in accordance with changing social practices and codes of behaviour (Alcaraz Varó and Hughes, 2002, p.25).

The translation of accounting terminology is affected by an additional problem, which is the existence of three accounting registers in English: one based on British English, one based on American English and one based on IASB terminology. While the latter is partly a mixture of the first two, it also contains new coinages (Mourier, 2004).

As we will illustrate in more detail below, the LSPs of different disciplines are subject to different problems and approaches in translation. In particular, there are differences between more and less culture-dependent domains. The registers of natural sciences, engineering and technology contain and require precision and exact definitions of terminology (Stolze, 1998). This means the possibilities for transnational registers and the use of CATs are greater. This is less often the case in history, law and social sciences, which contain more general terminology, as well as many mixed terms and borrowings from everyday language. Social sciences are thus not dependent on consistent taxonomies, but rather serve a description of processes, with interpretation of contexts (ibid.).

\section{TRANSLATION THEORIES}

\section{Language and Culture}

Language is closely related to culture (Evans, 2004; Kocbek, 2008a). The link between language, culture and thought is expressed in the Sapir-Whorf hypothesis, which suggests that speakers of different languages think in different ways because "[t]he "real world" is to a large extent unconsciously built up on the language habits of the group. No two languages are ever sufficiently similar to be considered as representatives of the same social reality' (Sapir, 1929/49, p. 162). Thus in its weak form ('linguistic relativity'), ${ }^{5}$ the Sapir-Whorf hypothesis suggests that people who speak different languages perceive and think about the world differently, that they evaluate external realities differently, and that their language and cultural knowledge relate to each other differently (Werner, 1994). In other words, ' $\ldots$ the division of reality is not identical from one language to another' (Glanert, 2008, p. 169). For example, '[t]here is no exact way to translate the French word bois. In English, it can be wood, timber, and even woods, as in 'a walk in the woods'; in Italian it can be both legno or bosco. In German it can be Holz or Wald, but in German Wald can stand for both forest and bois' (Eco, 2009, p.12, based on Hjelmslev, 1943). Other frequently cited examples of non-equivalence relate to kinship and colour terminology in different languages. 
In the terminology of Ferdinand de Saussure, both the signifier (the sound pattern or word) and the signified (the underlying concept) differ in different languages (Saussure, 1915/1960, pp.65-70). The meaning of each word within a language is determined by its place within the system of that language (ibid., pp.22-3, $113,127-8)$. This means that translation between languages is anything but straightforward: 'Since every language is ultimately sui generis - its categories being defined in terms of relations holding within the language itself - it is clear that formal correspondence is nearly always approximate' (Catford, 1965, p. 27); there are no 'mathematics-based concepts of semantic equivalence or one-to-one correspondence' (Venuti, 1995, p.18). Instead, translation is an exchange between different mindsets (Ho, 2004) and can never completely reproduce a text faithfully without at least some change in meaning occurring (Joseph, 1998). This applies even to terms for physical, material signifieds, but especially to the translation of manmade, abstract, intangible or theoretical concepts or LSP terminology, including accounting terms such as 'income', TFV or 'fair presentation'. Some shift in meaning inevitably occurs.

\section{Equivalence and Functionalism}

If there is no one-to-one correspondence, how can 'equivalence' in translation be operationalized? Historically, literal translation was favoured: that is, faithfulness to the letter of the source text. This was essential in both Biblical and legal translation and 'was underpinned by belief in the magical properties of the logos: if the wording was changed, the incantatory force might be lost' (Harvey, 2002, p. 180, with reference to Gémar, 1995, pp. 26-30 and Šarčević, 1997, pp. 23-48).

Such a literal approach is preferred by untrained translators and by those commissioning a translation but who have little awareness of what this involves (Adab, 2000, p. 227). However, it frequently makes no reference to the underlying socio-cultural context of the source text and is therefore likely to produce a less effective target text (Adab, 2000). Therefore, more recently, a functionalist approach to translation has been emphasized.

A functionalist approach suggests that a good translation is one that 'can be used by the intended reader for a pre-determined purpose' (Adab, 2001, p. 136). Equivalence, in terms of a functionalist approach, relates to a comparison of how the reader of the source text understood the text with how the reader of the target text understands it (Nida, 1993, p.116).

Within this paradigm, Vermeer (1978), Reiss (1986) and Reiss and Vermeer (1984/91) developed the so-called skopos theory, which 'reflects a general shift from predominantly linguistic and rather formal translation theories to a more functionally and socioculturally oriented concept of translation' (Schäffner, 2001, p. 235, emphasis original). It argues that the translation of scientific and academic texts, instructions and contracts must consider contextual factors. These include the culture of the target text reader and the function or purpose ('skopos') the translated text is to perform in this culture (Schäffner, 2001). Skopos theory stresses the 'importance of a clearly defined purpose (i.e. skopos) of a translation, the necessity for a precise and complete translation brief/commission, the assertion of the role of the translator as intercultural expert, and the application of the principle of cultural embeddedness of the source and target texts' (Kocbek, 2008a, p. 50). ${ }^{6}$ Although one function is generally dominant, a text may have different communicative functions; i.e. it may inform, instruct or appeal (Adab, 2001).

Skopos theory has been criticized in a number of respects. Although intended as a general theory, it is not suitable for literary translation. Also, although translations 
may meet their purpose, they may be stylistically or lexically poor. Finally, and most importantly, skopos theory defines translation very widely: its strategies may be more in line with text adaptation rather than translation - although in most cases it does not promote extremely free translation (see e.g. Schäffner, 2001).

Functional (or non-literal) approaches are more likely to be welcomed in some disciplines than in others. In particular, as will be seen below, the very wide definition of translation proposed by Reiss (1990) appears suitable for disciplines such as advertising. However, even disciplines such as law, which have traditionally favoured a literal approach, have been moving toward functional approaches to translation. These issues are explored below.

\section{LESSONS FROM OTHER DISCIPLINES}

\section{Law}

In law, translation can have serious and lasting consequences. For example, the founding document of the colony of New Zealand (the Treaty of Waitangi, 1840) conveys different meanings in the English and the Maori language versions (O'Malley et al., 2010, Chapter 1). This has given rise to political fallout that continues today (ibid., Chapter 9). ${ }^{7}$

Law is a very culture-dependent domain; legal cultures and traditions differ internationally and within nation states. Each law constitutes a system with its own vocabulary, concepts, rules and techniques for interpretation and is linked to a view of the social order itself which determines the way in which the law is applied and shapes the very function of the law in that society' (David and Brierley, 1985, p. 19).

Legal systems have been variously classified, based on historical background, degree of codification, legal institutions, sources of law etc. (see for example David and Brierley, 1985, pp.22-31; Zweigert and Kötz, 1998, pp.68-72). The two largest legal system families are civil law (also referred to as Romano-Germanic law, code law or continental European law) and common law. These two families form the legal systems of $80 \%$ of all countries (Kocbek, 2008b).

Legal language reflects the development and culture of the respective legal system. Meaning is derived from the legal system, not from the linguistic properties of terms (Cao, 2002), which means that ' $[\mathrm{m}]$ any languages and legal systems do not make the same distinctions as English does, and there may be no separate words for these different English terms' (Cao, 2007, p. 73). In other words, the different systems' terminology is inherently incongruent (Šarčević, 1989). There is no transnational register or 'universal' language to express universal legal concepts (Kocbek, 2008b).

This suggests that, in translation, a clash of legal traditions results in a lack of equivalent terminology and concepts (Smith, 1995). An abundance of examples can be found to illustrate this. ${ }^{8}$ In fact ' $[\mathrm{t}]$ he very term common law is difficult to render in translation' (Dodova, 1989, p. 69, emphasis original). In addition, where languages are related but legal systems are not (or are to a lesser extent), this may lead to the use of false cognates (or false friends): words which appear to be similar but have different meanings. Thus the English 'sentence' is not equivalent to the Spanish 'sentencia' (Alcaraz Varó and Hughes, 2002, p. 176; see also ibid., pp.41-3), and English the 'domicile' does not correspond to the German 'Domizil' and the French 'domicile' (Cao, 2007, p. 58). Even if apparently equivalent terminology is found, 'legal concepts or usage most often do not correspond in substance' (Cao, 2002, p. 338). While the terms' functions may overlap, they do not represent equivalent legal ideas and concepts. 
The difficulties inherent in legal translation mean that ' $[\mathrm{t}]$ ranslators of legal terminology are obliged therefore to practice comparative law' (de Groot, 1998, p. 21). This is explored by Brown (1995), who finds that neither conventional translation nor adoption of foreign terms (non-translation) solves the problem of translating Western legal terms in the former Soviet republics - a shift in meaning and usage typically occurs when terms are assimilated into a foreign legal culture (Šarčević, 1989; Brown, 1995). Not even describing an 'untranslatable' term in the target language can solve this problem because "different languages, each of them interacting in a specific way with the cultural, historical and sociological "reality", can never render a particular idea identically' (Glanert, 2008, p. 165).

Because of the lack of real equivalents, previous authors warn against the use of bi- or multilingual dictionaries. Šarčević (1989) argues that only conceptual dictionaries, which provide information on the degree of equivalence of terms and their suitability for translation, are reliable. Ideal bilingual law dictionaries would be syntheses of monolingual dictionaries (Šarčević, 1989, citing Paepcke, 1986), but these are rare.

An additional problem in legal translation is indeterminacy. Ambiguity can be intended to open up space for interpretation (Harvey, 2002), but the degree of indeterminacy differs between languages (Cao, 2007, p.80) and between different languages' legal registers. Interpretation is thus affected by the relative tightness of drafting in the different legal systems. In jurisdictions based on common law, more precise definitions are required than in those based on Roman law, and different hierarchies of interpretation apply. Thus the wording of the law is all-important, while the intention of the legislator can be considered only under narrowly defined circumstances. ${ }^{9}$ This demand for precision comes at the expense of clarity (Carpenter and Poore, 2010).

In continental (civil) law systems the rules of interpretation refer to the intention of the legislator, in a functional, or 'teleological' interpretation. Terminology has the function of opening semantic space/interpretation within specific boundaries (Busse, 1998) and legal language makes use of exact definitions less frequently than it does in common law, and is drafted in statements of general principle, with detail to be filled in by courts (Hunt, 2002), who may also be influenced by doctrine (scholars' opinions) (Šarčević, 1989).

While the deliberate ambiguity of legal texts ensures necessary flexibility for judges and courts, it creates an additional problem for translators. In practical terms, translators operationalize equivalence by drawing on the context or internal cohesion of source and target texts, which provide clues to resolve ambiguities (Alcaraz Varó and Hughes, 2002, p. 36). Also, while until the twentieth century literal translation and fidelity to the source text were the overriding criteria (Poon, 2005), fidelity is now defined with reference to equivalent legal effect and impact on the target text reader (Šarčević 1997, p. 71; Harvey, 2002). Therefore legal concepts are only successfully translated if they perform the same task, fulfil the same function or solve the same problem (Šarčević, 1989, citing Zweigert and Kötz, 1984, p.48). But although the translator frequently must choose between different ways of translating a source language concept into the target language, it is not her role to interpret ambiguities - that remains the domain of lawyers (Harvey, 2002; Cao, 2007, p. 80). Instead, she must aim to convey and preserve the linguistic uncertainty in translation, because any attempt to clarify and reduce ambiguity would potentially limit a court's future room for interpretation (Cao, 2007, p.80). However, since lawyers are conscious of the power of language, they remain at times reluctant to grant legal 
translators the freedom to translate as they see fit (Harvey, 2002, p. 181). This remains the case in spite of recent advances and more liberal approaches to legal translation.

\section{Advertising}

Advertising has the potential to offer new insights to translation studies; it 'provides us with a microcosm of almost all the prosodic, pragmatic, syntactic, textual, semiotic and even ludic difficulties to be encountered in translating' (ibid., p. 173; see also Munday, 2004). It also suggests strategies and methods (Smith and Klein-Braley, 1997). According to Shakir (1995), instances where the translator fails to communicate the intended meaning are of particular interest, for example 'the ways in which an advertisement may prove opaque to the translator, the linguistic givens in an advertisement that may enhance or impede translating, and the situative and cultural dimensions associated with the advertisement in question' (ibid., p. 63).

Translation errors are common, and some general problems apply: brand names may have to be altered to allow for differences in pronunciation or association, and to avoid unintentionally humorous or obscene connotations (Munday, 2004), ${ }^{10}$ and legal restrictions affecting the target market might hinder the most effective translation (Smith and Klein-Braley, 1997; Smith, 2006).

Translations are often unsatisfactory because of limitations of the translator, such as unfamiliarity with the subject matter and lack of creativity (Anholt, 1999, p.273; Ho, 2004). Other problems may be created by cost considerations or by marketing executives underestimating the difficulties of translation: 'In their minds, a person who can speak the language of the target market is good enough to undertake the translation job' (Ho, 2004, p. 239). Further, business leaders may not trust translators $(H o, 2004)$ and may attempt to restrict their creative freedom.

Poor or inappropriate translation in advertising is most common where the prestige of the translated text is low, such as in in-house literature or tourist brochures, while international newspapers and magazines show very high-quality language work (Smith and Klein-Braley, 1997, pp. 174-175). This appears to be thanks to the use of native speakers as copywriters and/or translators, "whose expertise goes beyond straight translation' (ibid., see also Ho, 2004).

Like law, advertising is a culture-dependent domain. Advertising texts contain a number of language and culture-specific values and associations which represent potential problems for translation (Adab, 2000). Different cultures can be reflected in consumers' 'popular taste' (Ho, 2004), preferences and needs; their differing degrees of vulnerability to persuasion (Sidiropoulou, 1998); and features of perception and values associated with product identity (Adab, 2001). Translated advertisements must influence the target reader in a specific fashion, and strategies and techniques, content and linguistic choices need to be adjusted to the target culture to achieve the desired effect (Sidiropoulou, 1998). Major problems are cross-cultural unawareness (Jettmarova et al., 1997) and cultural gaps, i.e. concepts missing in the target culture. For example, home insurance did not exist in the former Soviet Union (Cook, 1992, p.176, cited in Munday, 2004, p.209), and advertising itself was a new concept in transition economies (Jettmarova et al., 1997).

While often favoured by unskilled translators (including those in transitional economies), literal translation is especially unsuitable in advertising. It does not adjust to the (cultural) demands of the target market (Smith and Klein-Braley, 1997). It may result in a change in the function of the text, which then no longer achieves the intended result (Jettmarova et al., 1997; Munday, 2004). Not surprisingly, therefore, 
there is less emphasis on fidelity in advertising translation than in many other disciplines. Instead, emphasis is on 'expert intercultural text production' (Luque and Kelly, 2000, p. 235), and adaptation is the preferred approach (Smith and KleinBraley, 1997). This requires the translator to have cultural expertise and knowledge of consumer psychology and marketing strategies appropriate to the relevant culture (Ho, 2004), as well as, of course, good knowledge of the linguistic systems of the respective languages and the features of the specific register of the text to be translated (Shakir, 1995).

Advertising and advertising translation have been affected by globalization of products and services, increasingly reflecting a universal character (Guidère 2001). Multinational enterprises try 'to create their own universally recognized symbols to replace existing cultural symbols ...' (Smith, 2006, p. 175). As suggested by Ritzer's (1993) McDonaldization thesis, central policy planning results in an imposition of values and a reduction in intercultural differences (Adab, 2000). Translated advertisements import alien social values and linguistic patterns into the target culture, leading to new types of discourse and to ideological change (Jettmarova et al., 1997, Munday, 2004). However, single global advertising campaigns and global branding limit the effectiveness of translated advertisements in the target cultures (Smith, 2006).

\section{Medicine, Psychiatry, Psychology}

Cultural embeddedness also affects translation in some branches of medicine, psychiatry and psychology. Translation has grown in importance because of an increasing interest in cross-cultural comparison of patients, treatments and costs across languages and cultures (Knudsen et al., 2000).

This requires the semantic, conceptual and technical equivalence of different language versions of tests and research instruments (Knudsen et al., 2000), such as health-related quality of life (HRQL) questionnaires (Bowden and Fox-Rushby, 2003). Such instruments permit comparisons of results for different cultural/national groups, as well as the pooling of data from different countries (Sartorius and Kuyken, 1993; Eremenco et al., 2005). Most HRQL measures have been developed in English (Bowden and Fox-Rushby, 2003). Researchers have the options to use a research instrument untranslated; to translate it without modification; to adapt it; or to create a new research instrument for a different culture (van de Vijver and Leung, 1997). Direct (untranslated) application can show ethnocentric bias or fail to capture all aspects of the construct under investigation (ibid.). This is because perceptions of concepts such as 'quality of life' or 'pain'/'discomfort' are subject to different cultural interpretations (e.g. Sartorius and Kuyken, 1994; Kuyken et al., 1994). In spite of this, direct application appears common in psychology (van de Vijver and Leung, 1997) and in psychiatry (Knudsen, et al., 2000).

The importance of translation in medical disciplines is, however, reflected in a much more organized response to its problems than is the case in other fields. Reviews of literature and practice, as well as research studies, explore methods and provide guidance (e.g. Beaton et al., 2000; Bowden and Fox-Rushby, 2003; Acquardo et al., 2004; Eremenco et al., 2005; Wild et al., 2005; Acquardo et al., 2008) and researchers collaborate on international projects. ${ }^{11}$

Given the large quantity of research in this area, guidelines and recommendations of course differ, but a number of common themes emerge. For example, it is important for translators to carefully consider linguistic and cultural differences of the populations for whom the translated questionnaires are intended 
(van de Vijver and Hambleton, 1996). Also, to reduce translation problems, recommendations are provided on drafting the original instruments. ${ }^{12}$

Accepting that full equivalence is not achievable, it is important to minimize bias and achieve as high a level of equivalence as possible (Eremenco et al., 2005). It is labour intensive to produce high-quality translations, but the efficiency of translation can be improved by means of centralized review processes and standardized guidelines. According to the International Quality of Life Assessment (IQOLA) 'no one qualitative or quantitative step is sufficient to ensure a valid translation' (Bullinger et al., 1998, p. 913). ${ }^{13}$

Emphasis is on preserving meaning, which may require departing from a literal translation (Sireci et al., 2006). Back translation is frequently used to ensure the validity of translated instruments; however, Sumathipala and Murray (2000) consider this inadequate in psychiatry, and emphasize the benefits of group translation. This may however also be problematic 'because of group pressure to agree prematurely on translations' (Eremenco et al., 2005, p. 215).

In summary, there is considerable concern regarding translation in medicine and related disciplines, and a very large body of research literature reflecting this. More so than in advertising and law, for example, the approaches in this literature are pragmatic, exploring and comparing different practical methods. This may be because its focus, on research instruments and quality of life questionnaires, is a narrower one, likely to result in a finite number of the same types of problems.

\section{Natural Sciences, Technology and Engineering}

In natural sciences and related disciplines there is less 'vagueness' in terminology than in culture-dependent domains. The field of electricity, for example, is a typical example of a culture-independent domain where terminology is fixed and not open to interpretation: 'the degree of overlap between term systems from different national cultures is very much higher than in the culture-dependent domains' (Engberg, 2006, p. 680). This, of course, considerably eases translation.

In engineering, the difficulty in translation mainly rests with understanding precisely the meaning of the source text and correctly using the appropriate specialized (industry-related) terminology to convey the original meaning to the target audience (Shen, 2009). This is complicated by the fact that engineering consists of many specialized subdisciplines and interacts also with unrelated disciplines (law, insurance, finance, labour-relations, etc.). In order to achieve satisfactory results, translators not only need to have sufficient theoretical knowledge and practical experience, but must also be familiar with the specialized knowledge and terminology related to the industry (ibid.), including all areas of engineering. They also need to be able to correctly choose between a number of possible alternatives in a specialized context (Hann, 2004, p. xxii). Unfortunately, while translators are skilled in foreign languages and translation generally, sufficient specialized technical knowledge often seems lacking (Shen, 2009). To ease the task, vocabulary and context guidelines are offered inter alia by the International Organization for Standardization (ISO) and ASTM International (previously known as the American Society for Testing and Materials). Also, the relatively standardized language of science and technology makes computer-based translation more feasible than in more culture-dependent domains. Merkel (1996), however, found that while the attitude of translators towards the use of these tools, including translation memories, was generally positive, they may not always be willing to accept translations suggested by these. 


\section{IMPLICATIONS FOR POLICY AND RESEARCH}

The previous section explored research on translation in other disciplines. Below we examine the implications of this research for accounting. We begin by exploring practical problems and solutions, before discussing more fundamental ideological, cultural, legal and political concerns.

\section{Practical Implications for Translation in Accounting}

As in other disciplines, a number of problems exist in translation in accounting. Some of these problems may not be immediately obvious as arising from translation, because, while incomplete or incorrect application of IFRS may be due to translation errors, they may also be due to errors or deliberate manipulation by preparers, especially where auditing and enforcement are weak. Regulators may thus be unaware of when implementation and application problems result from translation.

The main cause of translation difficulties lies in the fact that different languages do not represent the same social reality (Sapir, 1929/49; Werner, 1994). There is, therefore, no one-to-one semantic equivalence between concepts in different languages and there are no translinguistic registers of specific disciplines and knowledge domains. Translation problems are exacerbated because disciplines such as accounting, law and medicine rely heavily on their specialized, culture-specific terminology. A clash of cultures (between, for example, common law and code law or Anglo-American and continental European accounting traditions) will result in a lack of equivalent concepts. Extreme care therefore needs to be taken over translation. Other disciplines, such as law and medicine, have acknowledged this and devote considerable resources to translation research. However, translation in accounting, while no less important and problematic, has been neglected.

Some translation problems relate to language-specific lexical or grammatical features. Other problems arise for operational reasons: the organization commissioning the translation may underestimate the task, may be constrained by cost considerations, or may be unwilling to grant translators the necessary creative freedom (see e.g. Adab, 2001; Ho, 2004). If such difficulties exist in accounting, it should be possible to address them. Drawing attention to these concerns, as we attempt in this paper, may contribute to doing so.

Translation literature in other disciplines emphasizes the training and skill of the translator. Inexperienced translators may mistakenly believe that literal means more faithful. This was the case in advertising translation in transitional economies (Jettmarova et al., 1997) and is likely to affect accounting translation in transitional and developing economies, because of a lack of understanding of imported, alien concepts, and a resulting lack of confidence in attempting functional translations.

As is evident from the experience of other disciplines, functional translation requires a high degree of language and translation proficiency, expertise in source and target languages, in the subject domain and in its linguistic register, and knowledge of source and target cultures and their respective conventions.

In accounting, in particular, lack of in-depth background knowledge is among the most serious reasons for poor-quality translations (Mourier, 1996, 2004). In fact, '[i]n financial reporting texts ... much is implied and the mere knowledge of terms is not sufficient to achieve high quality' (Mourier, 2004, p.146; see also Parker, 2001). As legal translators need to be experts in comparative law, accounting translators need to practice comparative international accounting.

Other disciplines have adopted a number of practical methods and approaches to translation. For example, in medicine a group approach is used. Group pressure 
may however lead to premature agreement on translation (Eremenco et al., 2005, p. 215). This observation may be relevant to the IFRS Foundation, whose translation policy involves group/committee work.

Aiming ' $[\mathrm{t}$ ]o ensure that IFRSs remain uniform across all languages and that translations are of the highest standards' (as Note 2), the IFRS Foundation provides a terminology list. This contains the terms that should be used in translation of IFRS, as well as their definitions (although only in English, and not for all terms). However, given the above observations on translatability, cultural embeddedness and lack of equivalence, and based on experiences in, inter alia, law, the translated terms are likely to carry different connotations in different accounting cultures. The expectation that IFRS remain uniform across all languages is therefore not realistic. If the terms previously existed in the target languages (i.e. are not new coinages or loan-words), they are likely to retain previous connotations (Evans, 2010). Where new concepts are introduced, new terms may have to be created. However, because the concepts are alien, these new terms might not be meaningful in the respective accounting tradition (cf. Zeff, 2007). For this reason, for example, the translation of 'fairness opinion' into French as 'attestation d'équité' may be harder to understand for some Frenchspeaking readers than the English term would be. ${ }^{14}$

The terminology list also contains inconsistencies, and more than one translation is offered for some terms, with no explanation of their differences. For example, it offers two translations each for 'fair presentation' into French and Italian but translates both 'balance sheet' and 'statement of financial position' into German as 'Bilanz', thus not reflecting the deliberate terminology change in English. ${ }^{15}$ (See also Nobes (2009), who explores and compares translations of TFV and of the 'fair presentation' requirement of IAS 1.)

These inconsistencies have little effect on a functionalist approach to translation: two possible terms for 'fair presentation' permit the translator to choose the term best fitting the context. Nonetheless, regulators may be concerned that such apparent inconsistencies in terminology lists may reduce (legal) certainty or lead to the loss of subtle distinctions.

It may also be argued that terminology lists are of limited benefit in culturedependent social science domains, which, unlike fields such as engineering, do not rely on consistent taxonomies (Stolze, 1998). This also applies in accounting (Mourier, 2004). Translations of standardized terminology may even be misleading (unless in the form of conceptual dictionaries ${ }^{16}$ ). Even directly transplanted terms and concepts take on different meanings in different cultural, legal or socio-economic contexts.

Another problem relates to the fact that, in spite of the IFRS Foundation's one-language-one-translation policy, there are two 'official' versions of IFRS translations for a number of EU languages, such as German, French and Spanish. One of these is managed by the IFRS Foundation's translation services, the other prepared by the EU. There are terminology differences between these versions as, for example, in the two German versions of IFRS 7, 8, 18, 32, and IFRIC $19 .{ }^{17}$ This suggests that the Foundation's concern that multiple versions might reduce comparability and legal certainty may be valid.

Where the need for translation is known from the outset (as in international law, accounting and medical research), the concerns of translation can be taken into account at the drafting stage. This requires careful consideration of the suitability of terms and concepts for different cultures, and also of the drafting style: for example, the passive voice, redundancies and complex syntax should be avoided, as should 
imprecise terms (see also Note 12; Wong, 2004, p. 11-12; Baskerville and Evans, 2011, pp.37-48, 50, 56-58). (The use of imprecise terms may be an exception where this is deliberate, i.e. where vagueness and room for interpretation are desired, as with expressions such as TFV.)

However, until recently, the needs of translators appear not to have played a significant role in standard-setting. According to Coman (2010, p. 45), 'the Japanese translations that have been produced to date really highlight that IFRSs have been designed by English speakers for English speakers, with long, wordy sentences containing language which is wide open to interpretation'. Some aspects of the drafting process, however, appear to be changing for the better: The IASB was intending to liaise with translation staff in finalizing the standard on revenue recognition. ${ }^{18}$ Further, it has moved from the use of 'should' to 'shall' in the English language versions of the standards, thus reducing ambiguity for language communities that have fewer means of expressing obligation than English does. ${ }^{19}$ It has also invited feedback on potential problems in exposure drafts and standards (IFRS Foundation, 2010, p. 2).

Simple translation errors are an additional, and not uncommon problem. ${ }^{20}$ In particular the quality of the EU translations has been questioned. In response, the Commission has initiated a detailed review of its translations (Commission of the European Communities, 2008). Once users become aware of errors in IFRS translations, the translated versions lose credibility. Errors can be corrected; however, a change in wording may be interpreted as an intended change in meaning, rather than a correction. For example, the change from 'should' to 'shall' (albeit not correcting an actual error) required an explanation: 'By replacing "should" with "shall", the Board does not intend to change the requirements in the Standards, but to clarify that it interprets "should" as meaning "shall". 21 To avoid the perception that a change in meaning is intended, consistency in terminology is therefore often preferred, even if this means that lower-quality translations are perpetuated.

An additional difficulty is presented by terminology shared between everyday language and a discipline's specialized LSP. For example, the German term 'Vorsicht' can be translated into English inter alia as 'attention', 'carefulness', 'caution', 'circumspection', 'prudence' or 'conservatism', but only the last two are appropriate in an accounting context. What may not be an obstacle to understanding in everyday communication could lead to significant misrepresentations or misunderstandings in a discipline-specific context where subtle distinctions need to be made. A further complication arises where accounting language shares terminology with other LSPs (economics, law, sociology), because the meanings of a term in the different disciplines are often not the same (for example 'asset' in law vis-a-vis in accounting).

Translation problems can have legal consequences: the Swedish version of IFRS 8 requires a company to disclose to what extent it has major customers, while the English original refers to the extent of reliance on major customers. The Swedish enforcement panel - relying on the Swedish translation - recently challenged a company for providing inadequate disclosure, although it appeared to be complying with the spirit, and the wording, of the original. ${ }^{22}$

A change in Indonesian law, although not explicitly referring to IFRS, provides a further illustration of concerns arising from translation: legal documents now need to be drafted in the Indonesian language, rather than English. This includes, potentially, all commercial documents, even if they are governed by US or English law. The translation is costly, and the legal uncertainty arising even more so (but this 
is seen as a potential source of revenue for Indonesian law firms). For example, the Indonesian language does not distinguish between 'guarantee' and 'security', and the concept of trust structure (in the context of bond indentures) does not exist. This has commercial consequences: some trustees have left the Indonesian market (Evans, 2009).

Finally, translation also has time and cost implications, which means IFRS implementation is not played on a level playing field. The time lag between publication of standards, interpretations and consultation documents in English and of their translations constitutes a barrier to conversion (Street and Larson, 2004). The time required for translation has delayed implementation, for example, in Turkey. ${ }^{23}$ Further, exposure drafts and other consultation material are not translated into all languages, ${ }^{24}$ thus excluding constituents from the standard-setting due process. Also, arrangements for covering the costs of translation differ between jurisdictions (as Note 24). In some, the costs are covered (at least in part) by national governments and/or professional associations. This may place disproportionate and undue burdens on smaller jurisdictions. This is also the case for the translation and implementation of International Standards on Auditing (Duhovnik, 2011).

\section{Accounting, Law and Indeterminacy}

In addition to the above practical implications, concerns arise from the inherent nature of language. On the one hand, equivalence between concepts and terminology in different cultures is limited. On the other hand, as with law, difficulties arise from the fact that language is inherently indeterminate, and meaning is context-dependent.

The degree of context required differs between languages. German is a lowcontext language and English a mid-context language (Smith and Klein-Braley, 1997), while Japanese is more ambiguous than English (see e.g. Hall, 1976, Chapter 7 ) and therefore requires more context for successful communication. There are also differences in the degree of indeterminacy in different LSPs. In contrast to, for example, natural sciences, the terminology of historical, legal and social sciences is typically not systematically derived or unambiguously defined, but is often controversial. Discourse requires interpretation of contexts and the reaching of consensus (Stolze, 1998). This also applies to accounting.

Accounting draws on different disciplines in its knowledge foundations and in its terminology (including law, behavioural sciences and economics). As a result, some of its terminology is technical, relatively unambiguous and therefore easy to translate, but that is not the case for most of its terms, which are based on other social science disciplines. The different assumptions and conceptual underpinnings of accounting are inherently indeterminate and inherently incommensurate (Zambon and Zan, 2000) because '[t]he multifaceted and unsteady interaction between different bodies of knowledge and accounting, affects the representation of the object of accounting itself, the aims it seems to be pursuing, and the information needs which are reckoned to be most relevant' (ibid., p. 800).

Terms such as 'asset', 'revenue' or 'return' are ambiguous, depending on the accounting context and framework in which they are used. The English terms 'depreciation', 'amortization' and 'impairment' have similar, but not identical meanings as the German 'Abschreibung' (any write-down, including depreciation and impairment) or the French 'amortissement' (depreciation, amortization) and 'dépréciation' (one-off write-down, e.g. impairment) (Alexander and Nobes, 2007, p. 186). Similarly, the interpretation of probability expressions is affected by culture and by translation (Doupnik and Richter, 2003, 2004; Doupnik and Riccio, 2006). 
As noted above, in legal texts ambiguity can be intended to open up space for interpretation (Harvey, 2002). This is the case to a greater extent in civil law than in common law, which places greater emphasis on precision and exact definitions than does civil law. Differences in rules of interpretation and the degree of semantic space inevitably present problems for translators. While they themselves are not allowed to 'interpret' in a legal sense, their translations must retain the same scope for interpretation by the court as the original, i.e. not be wider or narrower. To practice such a functionalist approach to legal translation appears to complement the tradition of functional or teleological interpretation of the law in continental legal interpretation. It may, however, be problematic for common law based systems, which interpret statutes more narrowly than civil law based systems (Grossfeld, 1989) and emphasize the wording of the law rather than the intention of the legislator.

These issues are also relevant for accounting. Accounting shares many features with law and there is a strong correlation between countries' legal systems and accounting systems (Salter and Doupnik, 1992), suggesting that 'cultural gaps' affect both similarly. In addition, differences in laws and legal systems impact on accounting through different degrees of investor protection, demands for different corporate governance frameworks, preferences for rules or guidelines, different overriding principles (prudence or TFV), etc.

As with law (see Cao, 2002; Kocbek, 2008a,b), the meaning of accounting terms depends on the respective accounting system rather than on any linguistic properties, and translatability of accounting terminology depends on how closely the accounting systems of source and target language are related. If they are not closely related, neither suitable terminology nor equivalent concepts exist. As in law, where accounting systems are relatively unrelated, apparently similar terms may be 'false friends'. For example, many languages have words that appear identical or similar to the English 'material', as in 'material difference', but the Swedish 'materiell' or the French 'materiel' are not good translations in this context because these terms tend to refer to something physical/tangible (Baskerville and Evans, 2011). It is also arguable whether the Portuguese 'virtualmente certo' would be an appropriate translation of 'virtually certain', because 'virtualmente' has connotations of 'unreal' or 'imagined'. A better translation would therefore be 'praticamente certo'. ${ }^{25}$

The conceptual conflicts arising from differences in legal systems became apparent during the implementation of European Union company law directives, where some of the underlying concepts (such as TFV and 'substance over form'), which had originated from a common law context, were then implemented into a Roman law legal framework. The differences in the conventions of drafting, in the indeterminacy of the legal language and in the underlying (legal) knowledge structures and assumptions here directly affected accounting, especially when these accounting rules became statute law. Thus much of the prior literature on translation in accounting identified problems arising from the translation of accounting concepts in the context of EU law harmonization (see above, for example Rutherford, 1983; Parker, 1989; Alexander, 1993; Ordelheide, 1993; Aisbitt and Nobes, 2001; KosmalaMacLullich, 2003; Albu et al., 2013). Although not usually explicitly explored in these terms, this literature illustrated the difficulty in translating across legal systems and LSPs with different degrees of indeterminacy. For example, Ordelheide (1993) argued that the non-literal translation of the fourth directive's TFV clauses was justified in the context of the drafting and interpretation rules governing German law. Similarly, Grossfeld (1989, p. 871) argued that the TFV override was not needed in the context of continental law and may only be 'a means to bring English techniques 
of interpretation in line with Continental traditions, which in turn govern the interpretation of EEC rules'.

Nobes $(2009$, pp. 421, 424) notes two cases of interpretation of TFV by the European Court of Justice (ECJ) which he considers misunderstandings 'by nonBritish lawyers of a form of words invented by British accountants'. Although Nobes considers at least the first of these an error by the ECJ, these cases also illustrate that the interpretation of TFV differs because of differences in language, accounting systems and law.

\section{Convergence, Rules and Principles}

Two considerations arise from the above for the Rules versus Principles debate in accounting. First, IFRS are assumed to be a principle-based accounting system, i.e. the standards are intended to outline general principles but not prescribe detail. This is in contrast to common law legal culture, which is characterized by tightness of drafting and richness of detail, but where little accounting regulation is included in statute law. Now the principle-based standards constitute law in the EU and many other jurisdictions. In the EU that means that they are subject to continental law legal interpretation, i.e. the teleological approach of civil law applies, even in the UK. This may mean, for example, that the British origin and meaning of TFV is irrelevant in the context of European interpretation.

Second, it is easier to translate rule-based standards (Baskerville and Evans, 2011, p.54), i.e. standards that prescribe a specific accounting treatment on the basis of detailed or quantifiable criteria. (This has been confirmed by a recent empirical study by Huerta et al. (2013); see above). For rule-based standards, a more literal translation is arguably possible. As in law, a literal approach is not suitable for the translation of accounting principles.

The translation of principles means preserving ambiguity, so as not to limit intended room for interpretation. But to choose the most appropriate interpretant among different possible ones means accepting inevitable gains and losses, and requires a process of negotiation (Eco, 2003, Chapter 2). In line with skopos theory, this means that the translator's role has changed: s/he is now to be an 'active participant in legal communication' (Šarčević, 1997, p. 3) and 'text producer' (ibid., p. 2). In principle-based standards, judgement is required not only of the accountant, but also of the translator.

At the extreme, a non-literal translation, as we propose is required for the translation of principles, may be more in line with text adaptation rather than translation per se (cf. Schäffner, 2001). While this may not be the standard-setter's or regulator's intention, if this is explicitly acknowledged and encouraged, it is commensurate with accounting convergence. It permits the recognition, exploration and acknowledgement of differences. Rather than (ultimately unsuccessful) attempts to eliminate and suppress such differences, non-literal translation requires the adaptation of the target text to the (accounting) culture of the target audience. ${ }^{26}$ It does, however, place the translator in a position of responsibility and power that may not be envisaged by the party commissioning the translation.

\section{Vested Interests}

Skopos theory suggests that translation needs to consider the intended function of the target text. This may differ from the function of the source text - the exact purpose of the translations of IFRS, as well as their target audience, may vary in different countries. Depending on the target culture's legal and accounting tradition, the 
function may be to provide guidance, which, in its application, is subject to judgement; in others it may be more akin to strict instruction. The inherent flexibility of accounting terminology can facilitate compromise: as long as different interpretations are possible, each party may have a different, and on its own terms acceptable understanding of the translated text's function and of what was agreed. For the reasons discussed above, this is more likely in the case of the translation of principles (rather than rules).

However, even translated IFRS are unlikely to be accessible to and used by the same stakeholders in all target cultures. The need for translation and interpretation can therefore create scope for new forms of discourse (e.g. commentaries and guidance), ideological change, change of occupational identities and, in some accounting cultures, jurisdictional conflicts between lawyers and accountants. Interpretation and translation can also be exploited. This is because translation increases the intrinsic ambiguity of accounting as a discipline. According to Zambon and Zan (2000, p. 800) ' ... accounting can potentially serve many interests as a tool of power, because its knowledge bases have an ambiguous theoretical status. ... It is the unstable knowledge underpinnings of this technique that can open up room for its discursive use in terms of power (Hopwood, 1987, 1992)'.

It is exactly the inherent flexibility of accounting that permits its 'vested use' (Zambon and Zan, 2000, p. 800). This results from the foundation of accounting in different disciplines, but also, as argued above, from the differences in semantic space inherent in the LSPs of these different disciplines - particularly legal language. This is increased by the ambiguity and incommensurability inherent in translation. Therefore, while translation may facilitate convergence, it is also vulnerable to the translator's cognitive, cultural or ideological bias, as well as to the vested interests of those commissioning the translation.

The exploitation of indeterminacy in the discourse surrounding international harmonization and convergence has been demonstrated, for example, in the transformations of the accounting rules of the EU's Fourth Directive. Ordelheide (1990) provides examples of both 'soft' and 'hard' transformations in Germany. In hard transformations, provisions were implemented literally, but the flexibility inherent in possible interpretations of the translated terminology was exploited to serve national interests. In soft transformations, the directive's rules were not implemented literally. This provided scope for even more divergent interpretations by national commentators, who, in the German accounting and Roman law legal tradition, play a leading role in determining the application of accounting law. Companies tend to follow prevailing opinions but have some flexibility in choosing between different interpretations. In particular, in the case of the soft transformations,

for each rule ... more or less numerous commentators of the law show up deeming an interpretation adequate or at least applicable which is in the sense of the former traditional way of accounting. Enterprises can then refer to these commentators and are thus practically enabled to maintain their previous accounting habits. (Ordelheide, 1990, p. 6)

Thus '[s]oft Transformations ... have been transformed ... in such a way that accounting according to the national laws makes results possible which do not comply with the intentions of the Council of the European Communities' (ibid., p, 12). This illustrates that 'a finely drafted statute ... is language used as power' (Dodova, 1989, p. 72) - even, and perhaps especially, if it can circumvent the intentions of a policy- 
maker.

Among the most controversial exploitations of the indeterminacy inherent in accounting rules was the case of the TFV implementation in Europe. The debate between Ordelheide $(1993,1996)$ and Alexander $(1993,1996)$ on the German implementation provides a typical illustration of diverging interpretations resulting from different legal and accounting cultures, and the implementation elsewhere also demonstrated that countries managed to impose their own culture on an alien concept (Parker, 1989; Nobes, 1993). This illustrates that the process of translation, and the interpretation therefore inevitably required, allow national regulators to adapt a foreign concept to local economic and political requirements.

In summary, the indeterminacy and ensuing need for interpretation of principles can facilitate compromise and convergence, but can also be exploited. A close literal translation may reduce the risk of deliberate exploitation but, as suggested by skopos theory, the target text is less likely to fulfil its intended function, and at worst, this may result in translations that are difficult to understand and therefore practically unusable. This requires users to draw on IFRS summaries and interpretations, as typically prepared by large accounting firms. This means that the power of interpretation and dissemination is transferred to these firms. ${ }^{27}$ Their interests may not necessarily reflect those of the wider stakeholder community, at least some of whom are de facto excluded from the IFRS implementation discourse because of language barriers.

\section{Cultural Convergence or Imperialism?}

Post-colonial translation experts have questioned the idealistic model of translation, which assumes equality among cultures and languages. Instead, it is argued, translation takes place within asymmetrical power relations and can act as a means of containment of other cultures (Bassnett, 1998, with reference to Niranjana, 1992, pp.1-3).

In the case of accounting, if the dissemination of thought is controlled by the most powerful players, it is likely that values relevant to large capital markets in developed Western economies are assumed to have global relevance. This applies, for instance, where accounting and corporate governance frameworks are implemented in economies, or for enterprises, for which they are not suitable. For example, IAS/IFRS were initially expected to be suitable for all entities. The realization that they were not, and that they were of limited use to economies with underdeveloped capital markets, eventually led to the IASB's SME project (see for example IASB, 2004). Notably, in the development of the SME standard, 'some members and senior technical staff of the IASB were opposed to the diversion of resources to the project, and the project manager reported directly to the IASB's chairman in order to protect the project from being sidelined' (Nobes, 2010, p. 215).

Anglo-American accounting systems and the English language are among the strongest cultural and linguistic influences on the IASB, and Anglo-Saxon legal notions are linked to IFRS (Schulze-Osterloh, 2003). For example, the IASB increasingly refers to legal concepts such as 'contract' and 'legally enforceable' - with reference to their common law meanings. The Information for Observers relating to the board meetings of 20 and 22 June 2006 (IASB, 2006) inter alia 'reviews some basic principles of contract law' (paragraph 7). In footnote 4 the document states: 'While we have referred to contract law as it exists in Canada, the United Kingdom and the United States, we understand that the basic principles on which we rely for the subsequent analysis also exist in other jurisdictions. ${ }^{28}$ This is an incorrect and 
ethnocentric assumption: For example, David and Brierley (1985, pp. 318-21, 359-60) argue that historical developments gave rise to peculiarities in English law and 'prevented ... a fully rational development of its institutions' (p.320). They refer to contract law in English and common law to illustrate this, and discuss, inter alia, differences in contract law between English and Romano-French law. Translation is therefore difficult because in code law countries users will attach different meanings to these notions, and some languages cannot convey these notions easily, which means that reference to the English original text is required. Japan, for example, is not a contract law based society - it relies on contracts to a significantly lesser extent than is the case in common law countries. Instead, rules and regulations are created to manage and control interaction and relationships, such as those covered by employment contracts in common law (as Note 27).

The IASB's approach may be based on a lack of awareness of other (nonAnglo-American) legal and accounting cultures; alternatively, it may be based on a conscious disregard of such differences. In either case, this means not only that other legal languages will be repressed (Schulze-Osterloh, 2003), but also that other concepts and traditions are suppressed or simply disregarded.

Other powers representing and expanding Anglo-American cultural influences contribute to these developments, and again language plays a major part. O'Malley (2010), exploring such changes in Italian law, points out that American investment banks are 'great agents of contractual and legal convergence'. Due to their influence, American-style (i.e. common law based)

contracts and specific clauses became more and more standard in both Italian and European deals, they inevitably also began to impact Italian (and other local European) corporate and capital markets contracts, both those drafted in English but governed by Italian law and even those drafted in Italian and subject to Italian law (O’Malley, 2010, p. 116).

In addition, Italian jurists who have been influenced by training in common law may draw on common law legal terminology and concepts (such as those relating to contracts) even when communicating in Italian in a civil law context. This leads to the use of false cognates and communication problems with their Italian colleagues who have not had similar common law (or English language) exposure (O'Malley, 2010).

\section{Lingua Franca}

A related issue is the increasing use of English as a lingua franca. IFRS have been implemented in many jurisdictions. However, unlike the EU or the United Nations, the IFRS Foundation has only one official and working language. While many of its staff and board members are bi- or multilingual, this is not the case for all. The exclusive use of English as a working language inevitably restricts consideration of solutions arising from other traditions.

English is also increasingly used as a working language in the EU Commission, in spite of the EU's multilingual policy. Some existing and new member states are better equipped than others to deal with this, partly because of foreign language education, partly because of the relative relationship of languages to each other. However, lack of language skills may disadvantage some nations in negotiations (Dollerup, 1996), and '.. . the recourse to English as a working language compels most of the participants in the various task forces to operate in a foreign 
tongue' (Glanert, 2008, p. 167). As a result, '[some] delegates are frustrated because, as one representative put it "we say what we are able to say, not what we wish to say", (Dollerup, 1996, p. 300).

Thus the use of English as a lingua franca may lead to a restriction of original thinking or cognitive processes (Traxel, 1979; Süllwold, 1980; Podder-Theising, 1984, p.138), not only for policy-makers but also for researchers, who are increasingly required to publish in English (Schröder, 1998). It also means that English terminology will be increasingly used in accounting discourse in other languages (see e.g. Evans, 2010). Finally, apart from affecting (and restricting) the way non-English speakers think about accounting, this increasing use of English also excludes some stakeholders from discourse, not only in the EU but also in the IASB due process. If discourse is predominantly in English, lack of English language competency has practical, academic, social and status implications. Thus, speaking English can, for non-native speakers, be similar to using a professional register, in that both signal membership of an occupational elite and exclude non-members. This, in turn, is particularly significant for stakeholders in countries where English is not widely spoken or taught as a second language.

\section{CONCLUSIONS}

Accounting has become increasingly international. As a result, translation is essential in international accounting harmonization. It is necessary in multinational enterprises, necessary for annual reports that start in languages other than English, necessary to facilitate the international adoption of IFRS, and necessary to provide equal access to the EU's laws and policies for all its citizens (European Commission, 2008). However, translation of accounting terminology and regulations is not straightforward.

While research into translation is taken seriously in other disciplines, and a large body of research explores problems and solutions in, inter alia, medicine and law, very little exists, by comparison, in accounting. We argue that there is a need for more research on translation in accounting, and that accounting research on translation can benefit from engagement with other disciplines.

By providing an overview of translation theory and translation research in selected other disciplines, this paper aimed to offer new insights for the translatability and interpretation of accounting regulation. We began by exploring examples of practical problems and possible approaches to addressing these. This led us to engage with the skills required of the translator, the limitations of literal translation and of terminology lists, the difficulty arising from the existence of two official translations of IFRS for some languages, and the need to consider translation at the drafting stage. We also discussed legal, time and cost implications of translation.

We also aimed to contribute new perspectives for the legal, cultural and sociolinguistic aspects of accounting language. We explored the implications of the foundation of accounting in different disciplines, and the cultural embeddedness and indeterminacy of legal and accounting language. As in law (Šarčević, 1989) different accounting systems' terminologies are inherently incongruent. Legal theory further suggests that legal languages differ with regard to precision and detail, according to the relevant legal system, and that where legal texts are ambiguous, this ambiguity must, as far as possible, be retained in translation. According to translation theory, the aim is now (as much as possible) to achieve equivalent effects on the target reader. As we argued above, this is also relevant for the translation of accounting - in particular the translation of principles. 
We also examined the rhetoric and power relations that language may serve. Functional, target-reader oriented translation requires interpretation and involves a process of negotiation (Eco, 2003, Chapter 2). Translation is therefore vulnerable to cognitive and cultural bias, to a vested exploitation of indeterminacy in language and to ideologically and pragmatically motivated distortions, as for example in the national implementation of international regulation. It places the translator in a position of responsibility and power that may not be envisaged by those commissioning the translation, and given the power of words, is unlikely to be encouraged.

We finally aim to dispel the assumption that translation is a peripheral problem. The importance of translation in accounting is underestimated because (i) if translations are poor, IFRS adopters look to the English original or to summaries and implementation guides prepared by the large accounting firms; (ii) problems caused by poor translation may be disguised by other problems, such as poor enforcement and auditing; and (iii) translation has limited effect on the most powerful constituents. The IASB's working language is English, and the English language and AngloAmerican accounting culture are also the dominant influences in developed economies and for the most powerful 'global players'.

Translation-related problems do however disenfranchise less powerful stakeholders, especially those with lesser English language competencies. Translation problems can delay implementation, exclude stakeholders from the IFRS consultation and implementation discourse, place undue and disproportionate costs on smaller jurisdictions and allow the most powerful players to control the dissemination of accounting thought.

These issues are important because, as argued above, accounting is not an objective technical discipline, but has political, social and economic consequences. It legitimates behaviour (Power, 2003) and is a technology of power. ${ }^{29}$ By choosing, changing or creating terminology, we set boundaries within which we think about our discipline, and which are likely to impact on jurisdictional claims and power relations (Potter, 1999; Evans, 2010).

On the other hand, translation - and an acknowledgement of its limitations may facilitate accounting convergence and compromise. It can contribute to allowing us to embrace, rather than suppress, differences in our accounting cultures, and permitting them to coexist.

\footnotetext{
Notes

${ }^{1}$ Because of the wealth of prior literature in these disciplines (in particular medicine and related sciences) our review has to be selective. Also, we do not examine literary translation, which is subject to different constraints (and solutions).

${ }^{2}$ IASC Foundation, The IFRS Foundation and its translation policies, available at http://www.ifrs.org/Use+around+the+world/IFRS+translations/IFRS+translations.htm

${ }^{3}$ IFRS Foundation Terminology Lookup, available for subscribers at http://eifrs.ifrs.org/eifrs/Terms

${ }^{4} \mathrm{We}$ are grateful to Philippe Bui (Autorité des Normes Comptables) for pointing this out. (Email exchange 30 August 2010.) See also IFRS Foundation (2010).

${ }^{5}$ The deterministic view of the strong form, which suggests that thinking is determined by language, is not now generally supported (Werner, 1994; Crystal, 1997, p.15; Joseph, 1998).

${ }^{6}$ Functional approaches to translation have also been developed by others, most notably Nord (e.g. Nord, 1997).

${ }^{7}$ The document, signed by Maori chiefs and British government officials, exists in different versions (see e.g. O'Malley et al., 2010, Chapter 1). According to the English versions, 'the Maori ceded "absolutely and without reservation all the rights and powers of Sovereignty" - and there was no mention of continued chiefly power' (Belich, 1996, p. 194). The Maori language version distinguishes
} 
between two forms of power: governorship (the remit of the British) and chieftainship (retained by the Maori). The latter was not referred to in the English versions. Belich argues that this difference may have been the result of a translation error, but was more likely 'a deliberate or semi-deliberate act of deceit by those who translated the treaty into Maori' (ibid.). He suggests that the 'interpreters shifted emphasis between English and Maori written versions in a direction that improved the chances of Maori consent' (ibid., p. 195).

${ }^{8}$ For example, the continental legal terms for professionals licensed to advise on legal matters (German 'Rechstanwalt', Italian 'avvocato', etc.) have no direct equivalents in common law based systems. They are usually translated in a variety of ways, as lawyer, advocate, solicitor, etc. - none of which however are direct equivalents of the Roman law terms (Kocbek, 2008a). For further examples of nonequivalence between apparently similar concepts/terms see for example David and Brierley (1985, pp.90, 334-335), Šarčević (1989) and Cao (2007, pp.58-59).

${ }_{9}^{9}$ In the U.K., Parliamentary discussion may only be considered in legal interpretation since the case of Pepper v Hart (1992), and only in specific circumstances.

${ }^{10}$ For example, Sherwood's Bundh sauces were renamed, as was the Buick Lacrosse in Canada, because of the names' obscene connotations in some language communities (Munday, 2004).

${ }^{11}$ Such as, for example, the International Quality of Life Assessment (IQOLA), which translates and validates health surveys and develops protocols for doing so (see e.g. Bullinger et al. 1998). Knudsen et al. (2000) and Becker et al. (2002) describe the European Psychiatric Services (EPSILON) group's strategies for the translation and cross-cultural adaptation of measurement instruments for schizophrenia, and van de Vijver and Hambleton (1996) and Sireci et al. (2006) discuss the guidelines for test translations developed by the International Test Commission (consisting of representative of different branches of psychology). Translation and validation services are also available from highly specialized commercial organizations such as the MAPI Institute, while the International Medical Interpreters Association, as a trade organization, focuses on educational requirements and professional standards and practice, and promotes research into medical translation.

${ }^{12}$ For example, sentences should be simple and avoid redundancies, the active rather than the passive voice should be used, pronouns should be avoided, as should metaphors, colloquialisms and imprecise expressions (such as 'soon' or 'often'), and specific terms should be used rather than more general ones (such as 'members of your family', which may include different individuals in different cultures) (Brislin, 1986, cited by van de Vijver and Hambleton, 1996).

${ }^{13}$ Acquardo et al. (2008) offer a selected review of relevant literature. They recommend a multistep approach and suggest a checklist of the steps in translation. Other approaches commonly used include: discussion between the research group and the translator, back translation, the use of focus groups (Knudsen et al., 2000), 'verifying the psychometric properties of the instrument in the target language' (ibid, p. 8; see also van Wijngaarden et al., 2000), the use of a modified Delphi approach (Eremenco et al., 2005) and validation by means of statistical and qualitative analyses (Sireci et al., 2006). Other measures to ensure validity include comparing translations created by independent translators, and ensuring the quality of translators (e.g. proficiency in the respective languages, familiarity with the respective cultures, understanding the subject domain) (Hambleton and Kanjee, 1995; Sireci et al., 2006; Acquardo et al., 2008).

${ }^{14}$ Email exchange with Dominique Jonkers, professional IFRS translator, 3 February 2011.

${ }^{15}$ This is not an oversight - the possibility of using alternative translations was debated during the translation of the 2007 revision of IAS1, but the reviewer chose to retain the term 'Bilanz'. We are grateful to Robin Bonthrone for pointing this out.

${ }^{16}$ See Cao (2007, pp. 54-5) for developments regarding such dictionaries in law and Mourier (2008) for developments in accounting. See also Fuertes Olivera et al. (2010) for an example of such a conceptual dictionary for accounting.

${ }^{17}$ Email exchange with Robin Bonthrone, professional IFRS translator, 21 January 2011.

${ }^{18}$ See IASB / FASB Meeting May 2012 Norwalk, Agenda paper 7C paragraph 49(b), available at http://www.ifrs.org/Meetings/IASB+May+2012.htm

${ }^{19}$ While English has many different ways to express obligation, such as 'may', 'might', 'could', 'should' and 'must', some languages cannot make these distinctions (Baskerville and Evans, 2011, p. 43).

${ }^{20}$ For example:

- IAS 24 Related Party Disclosures refers to 'dependants of that person', while the German translation refers to 'abhängige Angehörige' (IAS 24.9). Unlike the original, the translation implies that the dependant has to be a relative. 
- IAS 24.12 refers to the name of 'the ultimate controlling party', while the German version translates 'party' as 'Unternehmen' (enterprise).

- In IFRS 7.37 'impaired' has been translated as 'nedskrivningsbar' ('possible to write down') in Swedish (Dahlgren and Nilsson, 2012).

Other examples are provided in Niehus (2005), Tsakumis et al. (2009) and Hellmann et al. (2010).

${ }^{21}$ IASC Foundation (2002) Exposure Draft of Proposed Improvements to International Accounting Standards, available at http://www.drsc.de/docs/drafts/iasb/improvements_2002/improvement_intro.html

${ }^{22}$ We are grateful to Sven-Arne Nilsson for providing this example.

${ }^{23}$ IAS Plus. Use of IFRS by Jurisdiction. Available at http://www.iasplus.com/country/useias.htm

${ }^{24}$ Email exchanges with Robin Bonthrone and Roanne Hasegawa, professional IFRS translators, 11 and 12 June 2012.

${ }^{25}$ We are grateful to Cláudia Teixeira for providing this example. See also Doupnik and Riccio (2006).

${ }^{26}$ This occurred for example with the non-literal translations and implementations of the TFV in the Fourth Directive, where this concept was adapted to the importing accounting cultures' traditions (see above). However, whether appropriate or not, this was not intended by the Commission. More recent examples of non-literal translation from IFRS convergence and implementation include the following: (i) IAS 16 Property, plant and equipment is translated into Japanese as Yukeikoteishisan (有形固定 資産） which means fixed assets in English, because translations for property, plant and equipment would be too narrow to cover what is in the scope of IAS 16.

(ii) The expression 'profit and loss' used in IFRS is translated junsoneki（純損益） which are the characters for net, loss, profit. Without the character for net, the Japanese text would not be clear. (iii) IAS 36 Impairment of Assets is translated into German as 'Wertminderungen von Vermögenswerten'. The term used to translate impairment is not the one normally used (which would be 'ausserplanmässige Abschreibungen' - literally 'unscheduled depreciation'.) This different term may have been selected to distinguish impairment in IAS 36 from the traditional German method of accounting for impairment.

(iv) IAS 12.46 refers to tax rates that have been 'enacted or substantively enacted'. The simplest literal translation of 'enacted' into German would be 'erlassen' or 'beschlossen'. However, given the differences in legal processes in different jurisdictions, a literal translation of 'substantively enacted' is less obvious but is understood to refer to situations where the enactment process is virtually complete. This differs in different jurisdictions. In Germany it means legislation has been passed by both houses of parliament (Ernst \& Young, 2013, section 5.1.1). The translator chose a construct that could be back-translated as 'pronounced (or announced) in law' ('gesetzlich angekündigt').

We are grateful to Roanne Hasegawa and Markus Fuchs for providing these IFRS examples.

The explicit emphasis on the law ('gesetzlich') in example (iv) is commensurate with German accounting tradition, although this phrase (as a whole) is not borrowed from legal German.

${ }^{27}$ To some extent the large firms and accounting networks also have such an influence in an Englishlanguage environment, through publishing (International) GAAP summaries and interpretations. However, especially where translations are of poor quality, this influence is significantly increased in a non-English language environment. (Email exchange with Roanne Hasegawa, professional IFRS translator, 30 October 2011 and 11 June 2012.)

${ }^{28}$ We are grateful to Sonja Wüstemann for drawing our attention to this.

${ }^{29}$ As argued in some critical accounting research, drawing on the work of Foucault. See for example Hoskin and Macve (1986).

\section{References}

Acquardo, C., K. Conway, C. Giroudet and I. Mear (2004), Linguistic Validation Manual for Patient-Reported Outcomes (PRO) Instruments, Mapi Research Institute, Lyon.

Acquadro, C., K. Conway, A. Hareendran and N. Aaronson (2008), 'Literature Review of Methods to Translate Health-Related Quality of Life Questionnaires for use in Multinational Clinical Trials', Value in Health, Vol. 11, No. 3, pp. 509-21.

Adab, B. (2000), 'Towards a More Systematic Approach to the Translation of Advertising Texts', in A. Beeby, D. Ensinger and M. Presos (eds.), Investigating Translation, John Benjamins, Amsterdam, pp. 223-34. 
Adab, B. (2001), 'The Translation of Advertising: A Framework for Evaluation', Babel, Vol. 47, No. 2, pp. 133-57.

Adelberg, A.H. (1979), 'A Methodology for Measuring the Understandability of Financial Report Messages', Journal of Accounting Research, pp. 565-92.

Adelberg, A.H. and G.E. Farrelly (1989), 'Measuring the Meaning of Financial Statement Terminology: A Psycholinguistics Approach', Accounting \& Finance, Vol. 29, No. 1, pp. 33-61.

Aisbitt, S. and C. Nobes (2001), 'The True and Fair View Requirement in Recent National Implementations', Accounting \& Business Research (Wolters Kluwer UK), Vol. 31, No. 2, pp. 83-90.

Albu, C.N., N. Albu and D. Alexander (2013), 'The True and Fair View Concept in Romania: A Case Study of Concept Transferability', Research in Accounting in Emerging Economies, Vol. 13, pp. 61-90.

Alcaraz Varó, E. and B. Hughes (2002), Legal Translation Explained, St. Jerome, Manchester UK and Northampton, Mass.

Alexander, D. (1993), 'A European True and Fair View?', European Accounting Review, Vol. 2, No. 1, pp. 17-46.

Alexander, D. (1996), 'Truer and Fairer. Uninvited Comments on Invited Comments', European Accounting Review, Vol. 5, No. 3, pp. 483-93.

Alexander, D. and C. Nobes (2007), Financial Accounting: An International Introduction, Pearson/Financial Times, Harlow.

Allan, K. (2006), 'Jargon', in K. Brown, A.H. Anderson, L. Bauer, M. Berns, G. Hirst and J. Miller (eds.), The Encyclopedia of Language and Linguistics, 2nd ed., Elsevier, Amsterdam/Boston, pp. 109-112.

Anholt, S. (1999), Another One Bites the Grass: Creating International Advertising that Makes Sense, John Wiley, New York.

Archer, S. and S. McLeay (1991), 'Issues in Transnational Financial Reporting: A Linguistic Analysis', Journal of Multilingual \& Multicultural Development, Vol. 12, No. 5, pp. 347-61.

Athanassiou, P. (2006), The Application of Multilingualism in the European Union Context, Legal Working Papers Series ed., European Central Bank.

Bagranoff, N.A., K.A. Houghton and J. Hronsky (1994), 'The Structure of Meaning in Accounting: A Cross-Cultural Experiment', Behavioral Research in Accounting, Vol. 6, pp. 35-57.

Baskerville, R.F. and L. Evans (2011), The Darkening Glass: Issues for Translation of IFRS, Institute of Chartered Accountants of Scotland, Edinburgh.

Bassnett, S. (1998), 'Translating Across Cultures', in S. Hunston (ed.), Language at Work, British Association for Applied Linguistics/Multilingual Matters Limited, Clevedon/Philadelphia/Toronto/Sydney/Johannesburg, pp. 72-85.

Beaton, D.E., C. Bombardier, F. Guillemin and M.B. Ferraz (2000), 'Guidelines for the Process of Cross-Cultural Adaptation of Self-Report Measures', Spine, Vol. 25, No. 24, pp. 3186-91.

Becker, T., M. Knapp, H.C. Knudsen, A. Schene, M. Tansella, G. Thornicroft and J.L. Vázquez-Barquero (2002), 'The EPSILON Study-a Study of Care for People with Schizophrenia in Five European Centres', World Psychiatry, Vol. 1, No. 1, pp. 45.

Belich, J. (1996), Making Peoples: A History of the New Zealanders, from Polynesian Settlement to the End of the Nineteenth Century, Penguin Books (NZ), Auckland.

Bowden, A. and J.A. Fox-Rushby (2003), 'A Systematic and Critical Review of the Process of Translation and Adaptation of Generic Health-Related Quality of Life Measures in 
Africa, Asia, Eastern Europe, the Middle East, South America', Social Science \& Medicine, Vol. 57, No. 7, pp. 1289.

Brislin, R.W. (1986), 'The Wording and Translation of Research Instruments' in W.J.

Lonner, and L.W. Berry, Field Methods in Cross-Cultural Research. Cross-Cultural Research and Methodology Series, Vol. 8., Thousand Oaks, CA, US: Sage Publications, Inc, pp. 137-164.

Brown, C.E. (1995), 'Riding the Waves of Fortune: Translating Legislation of the Successor Soviet Republics', in M. Morris (ed.), Translation and the Law, VIII ed., John Benjamins Publishing Co., Philadelphia, pp. 67-83.

Bullinger, M., J. Alonso, G. Apolone, A. Leplège, M. Sullivan, S. Wood-Dauphinee, B. Gandek and P. Bech (1998), 'Translating Health Status Questionnaires and Evaluating their Quality: The IQOLA Project Approach. International Quality of Life Assessment', Journal of Clinical Epidemiology, Vol. 51, No. 11, pp. 913-23.

Busse, D. (1998), 'Die Juristische Fachsprache Als Institutionensprache (Am Beispiel Von Gesetzen Und Ihrer Auslegung)', in L. Hoffmann, H. Kalverkamper and H.E. Wiegand (eds.), Fachsprachen - Ein Internationales Handbuch Zur Fachsprachenforschung Und Terminologiewissenschaft, 2nd ed., de Gruyter, Berlin/New York, pp. 1382-91.

Cao, D. (2002), 'Finding the Elusive Equivalents in Chinese/English Legal Translation', Babel, Vol. 48, No. 4, pp. 330-41.

Cao, D. (2007), Translating Law, Multilingual Matters Limited, Clevedon.

Carpenter, M. and E. Poore (2010), 'Reading Legal English', in S. Ferreri (ed.), Falsi Amici e Trappole Linguistiche. Termini Contrattuali Anglofoni e Difficolta Di Traduzione, G. Giappichelli Editore, Torino, pp. 51-71.

Catford, J.C. (1965), A Linguistic Theory of Translation: An Essay in Applied Linguistics, Oxford University Press, London.

Chesley, G. (1986), 'Interpretation of Uncertainty Expressions', Contemporary Accounting Research, Vol. 2, No. 2, pp. 179-99.

Cook, G. (1992), The Discourse of Advertising, $2^{\text {nd }}$ ed., Routledge,

Coman, R. (2010), 'Japan Moves Towards IFRS', Chartered Accountants Journal, Vol. 89, No. 8, pp. 44-45.

Commission of the European Communities, (2008), Report from the Commission to the Council and the European Parliament on the Operation of Regulation (EC) No. 1606/2002, $19^{\text {th }}$ July 2002, on the Application of International Accounting Standards, Brussels.

Crystal, D. (1997), The Cambridge Encyclopedia of Language, Cambridge University Press, Cambridge.

Crystal, D. (2003), The Cambridge Encyclopedia Of The English Language, Cambridge University Press, Cambridge.

Dahlgren, J. and S. Nilsson (2012), 'Can Translations Achieve Comparability? The Case of Translating IFRSs into Swedish', Accounting in Europe, Vol. 9, No. 1, pp. 39-59.

David, R. and J.E.C. Brierley (1985), Major Legal Systems in the World Today: An Introduction to the Comparative Study of Law, 4th ed., Stevens \& Sons, London.

Davidson, R.A. and H.H. Chrisman (1994), 'Translations of Uncertainty Expressions in Canadian Accounting and Auditing Standards', Journal of International Accounting, Auditing and Taxation, Vol. 3, No. 2, pp. 187-203.

Davidson, R.A. and H.H. Chrisman (1993), 'Interlinguistic Comparison of International Accounting Standards: The Case of Uncertainty Expressions', International Journal of Accounting, Vol. 28, No. 1, pp. 1-16. 
De Groot, G.R. (1998), 'Language and Law', in E. Hondius (ed.), Netherlands Reports to the Fifteenth International Congress of Comparative Law, Intersentia, Antwerp/Groningen, pp. 20-32.

Deloitte (no date), 'IFRS by jursidiction', IAS Plus, retrieved 8 March 2014 from http://www.iasplus.com/en/resources/ifrs-topics/use-of-ifrs

Dodova, L. (1989), 'Translator Looks at English Law', Statute Law Review, Vol. 10, pp. 6978.

Dollerup, C. (1996), 'Language Work at the European Union', in M.G. Rose (ed.), Translation Horizons, Beyond the Boundaries of Translation Spectrum, Center for Research in Translation, State University of New York, Binghamton, pp. 297-314.

Doupnik, T.S. and E.L. Riccio (2006), 'The Influence of Conservatism and Secrecy on the Interpretation of Verbal Probability Expressions in the Anglo and Latin Cultural Areas', The International Journal of Accounting, Vol. 41, No. 3, pp. 237-61.

Doupnik, T.S. and M. Richter (2003), 'Interpretation of Uncertainty Expressions: A CrossNational Study', Accounting, Organizations and Society, Vol. 28, No. 1, pp. 15-35.

Doupnik, T.S. and M. Richter (2004), 'The Impact of Culture on the Interpretation of "in Context" Verbal Probability Expressions', Journal of International Accounting Research, Vol. 3, No. 1, pp. 1-20.

Duhovnik, M. (2011), 'Time to Endorse the ISAs for European use: The Emerging Markets' Perspective', Accounting in Europe, Vol. 8, No. 2, pp. 129-40.

Eco, U. (2003), Mouse Or Rat? Translation as Negotiation, Weidenfeld \& Nicolson, London. Eco, U. (2009), Experiences in Translation. University of Toronto Press, Toronto

Engberg, J. (2006), 'Languages for Specific Purposes', in K. Brown, A.H. Anderson, L. Bauer, M. Berns, G. Hirst and J. Miller (eds.), The Encyclopedia of Language and Linguistics, 2nd ed., Elsevier, Amsterdam, pp. 679-84.

Eremenco, S.L., D. Cella and B.J. Arnold (2005), 'A Comprehensive Method for the Translation and Cross-Cultural Validation of Health Status Questionnaires', Evaluation \& the Health Professions, Vol. 28, No. 2, pp. 212-32.

Ernst \& Young (2013) International GAAP 2013: Generally Accepted Accounting Principles under International Financial Reporting Standards, John Wiley \& Sons.

European Commission (2008), Speaking for Europe. Languages in the European Union Directorate-General for Communication, Brussels, retrieved 8 March 2014 from http://bookshop.europa.eu/en/speaking-for-europe-pbNAAB08127/

Evans, L. (2003), 'The True and Fair View and the 'fair presentation' override of IAS 1', Accounting and Business Research, Vol. 33, No. 4, pp. 311-25.

Evans, L. (2004), 'Language, Translation and the Problem of International Accounting Communication', Accounting, Auditing \& Accountability Journal, Vol. 17, No. 2, pp. 210-48.

Evans, L. (2010), 'Observations on the Changing Language of Accounting', Accounting History, Vol. 15, No. 4, pp. 439-62.

Evans, L. and C. Nobes (1996), 'Some Mysteries Relating to the Prudence Principle in the Fourth Directive and in German and British Law', European Accounting Review, Vol. 5, No. 2, pp. 361-373.

Evans, R. (2009), 'Which Bits do I Translate?', International Financial Law Review, Vol. 28, November, pp. 24-25.

Fuertes Olivera, P., P.G. Gómez, M.N. Amo, A.S. Ruano, A.d.l.R. Rodicio, M.A.S. Ruano, M.V. Sacristán, S. Nielsen, L. Mourier, H. Bergenholtz and R. Almind (2010), El Diccionario Inglés-Español De Contabilidad, Thomson Reuters, Pamplona. 
Gémar, J.C. (1995), Traduire Ou l'art d'interpréter. Fonctions, Statut Et Esthétique De La Traduction. Tome 1: Principes, Les Presse de l'Université du Québec, Québec.

Glanert, S. (2008), 'Speaking Language to Law: The Case of Europe', Legal Studies, Vol. 28, No. 2, pp. 161-71.

Grossfeld, B. (1989), 'Common Roots of the European Law of Accounting', International Lawyer, Vol. 23, No. 4, pp. 865-72.

Guidère, M., (2001), 'Translation Practices in International Advertising', Translation Journal [on-line serial], Vol. 5 No. 1, retrieved 8 March 2014 from http://translationjournal.net/journal//

Hall, E.T. (1976), Beyond Culture, Anchor Press, New York.

Hambleton, R. K. and A. Kanjee (1995), 'Increasing the validity of cross-cultural assessments: Use of improved methods for test adaptations', European Journal of Psychological Assessment, Vol. 11, No. 3, pp. 147.

Hann, M., (2004), 'A Basis for Scientific and Engineering Translation: German-EnglishGerman'. John Benjamins.

Haried, A.A. (1973), 'Measurement of Meaning in Financial Reports', Journal of Accounting Research, pp. 117-45.

Haried, A.A. (1972), 'The Semantic Dimensions of Financial Statements', Journal of Accounting Research, pp. 376-91.

Harvey, M. (2002), 'What's so Special about Legal Translation?', Meta: Journal Des Traducteurs, Vol. 47, No. 2, pp. 177-85.

Hellmann, A., H. Perera and C. Patel (2010), Equivalence of IFRS across Languages: Translation Issues from English to German, Conference presentation at Asia Pacific Interdisciplinary Research in Accounting Conference, Sydney, July.

Hjelmslev, L. (1943 [1968]), Prolegomena to a Theory of Language, Univ of Wisconsin Press, Madison.

Ho, G. (2004), 'Translating Advertisements across Heterogeneous Cultures', The Translator: Studies in Intercultural Communication, Vol. 10, No. 2, pp. 221-43.

Hopwood, A.G. (1987), 'The Archeology of Accounting Systems', Accounting, Organizations and Society, Vol. 12, No. 3, pp. 207-34.

Hoskin, K.W. and R.H. Macve (1986), 'Accounting and the Examination: A Genealogy of Disciplinary Power', Accounting, Organizations and Society, Vol. 11, No. 2, pp. 10536.

Houghton, K.A. and J.J.F. Hronsky (1993), 'The Sharing of Meaning between Accounting Students and Members of the Accounting Profession', Accounting \& Finance, Vol. 33, No. 2, pp. 131-47.

Huerta, E., Petrides, Y., and Braun, G. P. (2013). 'Translation of IFRS: Language as a barrier to comparability', Research in Accounting Regulation, Vol. 25 No. 1, pp. 1-12.

Hunt, B. (2002), 'Plain Language in Legislative Drafting: Is it really the Answer?', Statute Law Review, Vol. 23, No. 1, pp. 24-46.

IASB (2008), Five Questions on IFRS Adoption, IASB Insight, May pp.8-9

IASB (2004) Discussion Paper. Preliminary Views on Accounting Standards for Small and Medium-Sized Entities. IASB, London

IASB / FASB (2012), Norwalk Meeting May, Agenda paper 7C paragraph 49(b), retrieved 8 March 2014 from http://www.ifrs.org/Meetings/IASB+May+2012.htm

IASB (2006), Information for Observers, Conference presentation at Board Meeting: 22nd June 2006, IASB, London.

IASC Foundation (2014), The IFRS Foundation and its translation policies, retrieved 8 March 2014 from 
http://www.ifrs.org/Use+around+the+world/IFRS+translations/IFRS+translations.htm

IFRS Foundation (2014), Terminology Lookup, retrieved 8 March 2014 from http://eifrs.ifrs.org/eifrs/Terms.

IFRS Foundation, (2010), IFRS Translations Update, retrieved 8 March 2014 from http://www.ifrs.org/Documents/files/TransUpdateMay10.pdf, May.

International Quality of Life Assessment, retrieved 8 March 2014 from http://www.iqola.org/.

Jettmarová, Z., M. Piotrowska and I. Zauberga (1997), 'New Advertising Markets as Target Areas for Translation', in M. Snell-Hornby, Z. Jettmarová and K. Kaindl (eds.), Translation as Intercultural Communication, Selected Papers, John Benjamins, Amsterdam/Philadelphia, pp. 185-94.

Joseph, J.E. (1998), 'Why Isn't Translation Impossible?', in S. Hunston (ed.), Language at Work, Multilingual Matters Limited, Clevedon, pp. 86-97.

Kocbek, A. (2008a), 'The Cultural Embeddedness of Legal Texts', Journal of Language \& Translation, Vol. 9, No. 2, pp. 49-70.

Kocbek, A. (2008b), 'The Challenges of Intercultural Legal Communication', The International Journal of Euro-Mediterranean Studies, Vol. 1, No. 1, pp. 53-71.

Kosmala-MacLullich, K. (2003), 'The True and Fair View Construct in the Context of the Polish Transition Economy: Some Local Insights', European Accounting Review, Vol. 12, No. 3, pp. 465-87.

Knudsen, H. C., J. L. Vazquez-Barquero, B. Welcher, L. Gaite, T. Becker, and D. Chisholm, (2000), 'Translation and Cross-Cultural Adaptation of Outcome Measurements for Schizophrenia - EPSILON Study 2', British Journal of Psychiatry, Vol. 177.

Kuyken, W., J. Orley, P. Hudelson and N. Sartorius (1994), 'Quality of Life Assessment across Cultures', International Journal of Mental Health, pp. 5-27.

Luque, A. F., and Kelly, D. (2000). 'The Translator as Mediator in Advertising Spanish Products in English-Speaking Markets', in Beeby, A., Ensinger, D., and Presas, M. (ed.), Investigating Translation, John Benjamins, Amsterdam \& Philadelphia, pp. 23542

Merkel, M., (1996), 'Consistency and Variation in Technical Translations - A Study of Translators' Attitudes. Proceedings from "Unity in Diversity", Translation Studies Conference, Dublin, pp.137-49

Mills, P.A. (1989), 'Words and the Study of Accounting History', Accounting, Auditing \& Accountability Journal, Vol. 2, No. 1.

Mourier, L. (1996), 'Translation Challenges and Quality Problems in Financial Reporting', in A. Grinsted (ed.), Language and Business Life, Southern Denmark Business School, Kolding, pp. 327-44.

Mourier, L., (2004), 'Communicating Financial Reporting Across Continents', Hermes, Journal of Linguistics, Vol. 32.

Mourier, L., (2008), 'Mapping Global English Accounting Terminology in a Multifunctional Electronic Dictionary - A Contribution to Standardising Global English within a Specific Domain', Paper presented at the GlobEng conference, Verona.

Munday, J. (2004), 'Advertising: Some Challenges to Translation Theory', The Translator: Studies in Intercultural Communication, Vol. 10, No. 2, pp. 199-219.

Nida, E. A., (1993), Language, Culture and Translating, Shanghai Foreign Language Education Press.

Niehus, R.J. (2005), 'Die IFRS Auf Deutsch, Fehler Und Unzulaenglichkeiten Der Uebersetzung', Der Betrieb, Vol. 58, pp. 2477-83. 
Niranjana, T. (1992), Siting Translation: History, Post-Structuralism, and the Colonial Context, University of California Press, Los Angeles.

Nobes, C. (1993), 'The True and Fair View Requirement: Impact on and of the Fourth Directive', Accounting and Business Research, Vol. 24, No. 93, pp. 35-48.

Nobes, C. (2006), 'The Survival of International Differences Under IFRS: Towards a Research Agenda', Accounting and Business Research, Vol. 36, No. 3, pp. 233-45.

Nobes, C. (2009), 'The Importance of being Fair: An Analysis of IFRS Regulation and Practice - a Comment', Accounting \& Business Research (Wolters Kluwer UK), Vol. 39, No. 4, pp. 415-27.

Nobes, C. (2010), 'On Researching into the use of IFRS by Private Entities in Europe', Accounting in Europe, Vol. 7, No. 2, pp. 213-26.

Nord, C. (1997), Translating as a Purposeful Activity: Functionalist Approaches Explained, St. Jerome Publications, Manchester.

Oliver, B.L. (1974), 'The Semantic Differential: A Device for Measuring the Interprofessional Communication of Selected Accounting Concepts', Journal of Accounting Research, pp. 299-316.

Ordelheide, D. (1990), 'Soft Transformations of Accounting Rules in the 4th Directive in Germany', Les Cahiers Internationaux De La Comptabilite, Vol. 3, pp. 1-15.

Ordelheide, D. (1993), 'True and Fair View', European Accounting Review, Vol. 2, No. 1, pp. 81-90.

Ordelheide, D. (1996), 'True and Fair View: A European and a German Perspective', European Accounting Review, Vol. 5, No. 3, pp. 495-506.

Osgood, C.E., G.J. Suci and P.H. Tannenbaum (1957), The Measurement of Meaning, University of Illinois Press, Chicago.

O’Malley, P., (2010), 'Straddling the Line between the Anglo-American and Italian Contracts Worlds: the Experience of an American Corporate and Capital Market Attorney, on the Verge of Change' in S. Ferreri (ed.), Falsi Amici e Trappole Linguistiche. Termini Contrattuali Anglofoni e Difficoltà di Traduzione, Giappichelli.

O'Malley, V., B. Stirling and W. Penetito (2010), The Treaty of Waitangi Companion: Maori and Pakeha from Tasman to Today, Auckland University Press, Auckland.

Paepcke, F. (1986), 'Zum Problem Von Sprache Und Recht', in K. Berger and J.M. Speier (eds.), Im Übersetzen Leben, Narr., Tübingen, pp. 242-270.

Parker, R. H., (2001) 'Read with Care: Financial Reporting Translations', Accountancy, June, p.102

Parker, R.H. (1989), 'Importing and Exporting Accounting: The British Experience', in A. Hopwood (ed.), International Pressures for Accounting Change, Prentice Hall London, Hemel Hempstead, UK, pp. 7-29.

Podder-Theising, I. (1984), Hindus Heute. Materialien Zu Einer Sozialpsychologie Der Städtischen Mittelklasse, Verlag Peter Lang, Frankfurt aM.

Poon, W. Y. E. (2005). 'The cultural transfer in legal translation', International Journal for the Semiotics of Law, Vol. 18, No. 3, 307-23.

Potter, B. (1999), 'The Power of Words: Explaining Recent Accounting Reforms in the Australian Public Sector', Accounting History, Vol. 4, No. 2, pp. 43-72.

Power, M.K. (2003), 'Auditing and the Production of Legitimacy', Accounting, Organizations and Society, Vol. 28, No. 4, pp. 379-94.

Reiss, K., (1990), Das Missverständniss vom Eigentlichen Übersetzen', in R. Arntz, and G. Thorne (eds.), Übersetzungswissenschaft. Ergebnisse and Perspektiven, Narr., Tübingen, pp. 40-53. 
Reiss, K. (1986), 'Übersetzungstheorien Und Ihre Relevanz Für Die Praxis', Lebende Sprachen, Vol. 31, No. 1, pp. 1-5.

Reiss, K. and H.J. Vermeer (1984/91), Grundlegung Einer Allgemeinen Translationstheorie, 2nd ed., Niemeyer, Tübingen.

Riahi-Belkaoui, A. and R.D. Picur (1991), 'Cultural Determinism and the Perception of Accounting Concepts', The International Journal of Accounting, Vol. 26, No. 2, pp. 118-30.

Ritzer, G. (1993), The McDonaldization of Society: An Investigation into the Changing Character of Contemporary Social Life, Pine Forge Press, Thousand Oaks, CA

Rutherford, B. (1983), 'Spoilt Beauty: The True and Fair View Doctrine in Translation', AUTA (Association of University Teachers in Accounting) Review, pp. 33-36.

Salmond, V. (1998), 'The Development of Special Registers in English: A Historical Review', in L. Hoffmann, H. Kalverkämper and H.E. Wiegand (eds.), Fachsprachen. Languages for Special Purposes. An International Handbook of Special-Language and Terminology Research, de Gruyter, Berlin and New York, pp. 2502-11.

Salter, S.B. and T.S. Doupnik (1992), 'The Relationship between Legal Systems and Accounting Practices: A Classification Exercise', Advances in International Accounting, Vol. 5, No. 1, pp. 3-22.

Sapir, E. (1929/1949), 'The Status of Linguistics as a Science' Selected Writings of Edward Sapir in Language, Culture, and Personality, University of California Press, Berkeley/Los Angeles, Washington DC, pp. 207-14.

Šarčević, S. (1989), 'Conceptual Dictionaries for Translation in the Field of Law', International Journal of Lexicography, Vol. 2, No. 4, pp. 277-93.

Šarčević, S. (1997), New Approach to Legal Translation, Kluwer law international, The Hague.

Sartorius, N. and W. Kuyken (1994), 'Translation of Health Status Instruments', in J. Orley and W. Kuyken (eds.), Quality of Life Assessment: International Perspectives, Springer Verlag, Berlin, pp. 3-18.

Saussure, F.D. (1915/1960), Course in General Linguistics, Owen, London.

Schäffner, C. (2001), 'Skopos Theory', in M. Baker (ed.), Routledge Encyclopedia of Translation Studies, Routledge, London \& New York, pp. 235-38.

Schröder, H. (1998), 'Heutige Fachsprachen Im Interkulturellen Austausch III: Die Stellung Der Englischen Wissenschaftssprachen Der Welt', in L. Hoffmann, H. Kalverkämper and H.E. Wiegand (eds.), Handbücher Zur Sprach-Und Kommunikationswissenschaft, de Gruyter, Berlin/New York, pp. 828-40.

Schulze-Osterloh, J. (2003), 'International Rechnungslegung Für Den Einzelabschluß Und Für Unternehmen Die Den Öffentlichen Kapitalmarkt Nicht in Anspruch Nehmen', Zeitschrift Für Wirtschaftsrecht, Vol. 24, No. 3, pp. 93-101.

Shakir, A., (1995),'The Translation of Advertisements: Registeral and Schematic Constraints', Meta, Vol. 40, No. 1, pp. 62-72.

Shen, Y. (2009), 'How to perfect the interpretation and translation in engineering projects', International Journal of Marketing Studies, Vol. 1, pp. 16-18.

Sidiropoulou, M. (1998), 'Advertising in Translation: English Vs. Greek', Meta: Journal Des Traducteurs, Vol. 43, No. 2, pp. 191-204.

Sireci, S. G., Yang, Y., Harter, J., and Ehrlich, E. J. (2006). 'Evaluating guidelines for test adaptations: A methodological analysis of translation quality', Journal of CrossCultural Psychology, Vol. 37, No. 5, pp. 557-67.

Smith, K. (2006), 'Rhetorical figures and the translation of advertising headlines', Language and Literature, Vol. 15, No. 2, pp. 159-82. 
Smith, S.A. (1995), 'Culture Clash: Anglo-American Case Law and German Civil Law in Translation', Translation and the Law 8, pp. 179-97.

Smith, V. and C. Klein-Braley (1997), 'Advertising - A Five-Stage Strategy for Translation', Translation as Intercultural Communication, John Benjamins, Amsterdam/Philadelphia, pp. 173-84.

Stolze, R. (1998), 'Die Rolle Von Fachsprachen Im Kontact Von Einzelsprachen III: Fachübersetzung in Den Geistes-Und Socialwissenschaften', in L. Hoffmann, H. Kalverkämper and H.E. Wiegand (eds.), Fachsprachen. Languages for Special Purposes. an International Handbook of Special-Language and Terminology Research, de Gruyter, Berlin and New York, pp. 784-91.

Street, D.L. and R.K. Larson (2004), 'Large Accounting Firms' Survey Reveals Emergence of "Two Standard" System in the European Union', Advances in International Accounting, Vol. 17, pp. 1-29.

Süllwold, F. (1980), 'Wissenschaftspsrache Und Originalität', Psycholgische Beiträge, Vol. 22, pp. 191-203.

Sumathipala, A., and Murray, J. (2000), 'New approach to translating instruments for crosscultural research: a combined qualitative and quantitative approach for translation and consensus generation', International Journal of Methods in Psychiatric Research, Vol. 9, No. 2, pp. 87-95.

Traxel, W. (1979), „Publish Or Perish!“-auf Deutsch Oder Auf Englisch’, Psychologische Beiträge, Vol. 21, pp. 62-77.

Tsakumis, G.T., D.R. Campbell and T.S. Doupnik (2009), 'IFRS: Beyond the Standards', Journal of Accountancy, Vol. 207, No. 2, pp. 34-39.

Van de Vijver, F., \& Hambleton, R. K. (1996). Translating tests: Some practical guidelines. European Psychologist, Vol. 1 No. 2, pp. 89-99.

Van de Vijver, F. J. R., \& Leung, K. (1997). Methods and data analysis of comparative research. in J. W. Berry, Y. H. Poortinga, and J. Pandey (Eds.), Handbook of crosscultural psychology, Vol. 1: Theory and Method, 2nd ed., Boston: Allyn \& Bacon, pp. 257-300).

Van Wijngaarden, B., Schene, A. H., Koeter, M., Vázquez-Barquero, J.L., Knudsen, H.C., Lasalvia, A. and McCrone, P. (2000). Caregiving in schizophrenia: Development, internal consistency and reliability of the involvement Evaluation Questionnaire European Version. EPSILON Study 4. British Journal of Psychiatry, Vol. 177, No. 39 pp. s21-s27.

Venuti, L. (1995), The Translator's Invisibility: A History of Translation, Routledge, London.

Vermeer, H.J. (1978), 'Ein Rahmen Für Eine Allgemeine Translationstheorie', Lebende Sprachen, Vol. 23, No. 3, pp. 99-102.

Werner, O. (1994), 'Sapir-Whorf Hypothesis', in R.E. Asher and J.M.Y. Simpson (eds.), The Encyclopedia of Language and Linguistics, Pergamon Press, Oxford.

Wild, D., A. Grove, M. Martin, S. Eremenco, S. McElroy, A. Verjee-Lorenz and P. Erikson (2005), 'Principles of Good Practice for the Translation and Cultural Adaptation Process for Patient-Reported Outcomes (PRO) Measures: Report of the ISPOR Task Force for Translation and Cultural Adaptation', Value in Health, Vol. 8, No. 2, pp. 94-104.

Wong, P. H. Y. (2004). Challenges and successes in implementing international standards: achieving convergence to IFRSs and ISAs. New York: International Federation of Accountants. 
Yankova, D. (2008), 'The Text and Context of EU Directives: Implications for Translators', Ibérica: Revista De La Asociación Europea De Lenguas Para Fines Específicos (AELFE), No. 16, pp. 129-46.

Zambon, S. and L. Zan (2000), 'Accounting Relativism: The Unstable Relationship between Income Measurement and Theories of the Firm', Accounting, Organizations and Society, Vol. 25, No. 8, pp. 799-822.

Zeff, S.A. (1990), "The English-Language Equivalent of "Geeft Een Getrouw Beeld", 'Appendix I'in', in R.H. Parker and C.W. Nobes (eds.), An International View of True and Fair Reporting, Routledge, London/New York, pp. 131-33.

Zeff, S.A. (2007), 'Some Obstacles to Global Financial Reporting Comparability and Convergence at a High Level of Quality', The British Accounting Review, Vol. 39, No. 4, pp. 290-302.

Zweigert, K. and H. Kötz (1984), Einführung in Die Rechtsvergleichung, 2nd ed., Mohr., Tübingen.

Zweigert, K. and H. Kötz (1998), Introduction to Comparative Law, 3rd ed., Clarendon Press, Oxford. 